\title{
Impact of value-driven scenarios on the geomorphology and ecology of lower Rhine floodplains under a changing climate
}

\author{
Menno Straatsma a,b,d,*, Aafke Schipper ${ }^{\mathrm{b}, \mathrm{d}}$, Marcel van der Perk ${ }^{\mathrm{a}, \mathrm{d}}$, Claus van den Brink ${ }^{\mathrm{c}}$, \\ Rob Leuven ${ }^{\text {b,d }}$, Hans Middelkoop ${ }^{\text {a,d }}$ \\ a Faculty of Geosciences, Department of Physical Geography, Utrecht University, PO Box 80115, 3508 TC, Utrecht, The Netherlands \\ ' Department of Environmental Science, Institute for Water and Wetland Research, Radboud University, PO Box 9010, 6500 GL, Nijmegen, The Netherlands \\ ${ }^{\mathrm{c}}$ Duurzame Rivierkunde, Hoenloseweg 3, 8121 DS, Olst, The Netherlands \\ d NCR, Netherlands Centre of River Research, Delft, The Netherlands
}

\section{A R T I C L E I N F O}

\section{Article history:}

Received 1 July 2008

Received in revised form 23 March 2009

Accepted 22 April 2009

Available online 28 May 2009

\section{Keywords:}

Biodiversity values

Food web exposure modeling

River floodplain deposition

Hydrodynamics

Scenario development

Value systems

\begin{abstract}
A B S T R A C T
The biogeomorphological functioning of lowland floodplains will be altered strongly due to future landscaping measures that are necessitated by climate change. For many industrialized and urbanized river basins, the layout of the fluvial area depends on the human choices for landscaping measures, which reflect the dominant value system of the actors. We aimed at (1) designing scenarios for the future layout of the floodplains of the River Waal in the Netherlands for 2050 using a new value-based methodology, and (2) assessing the floodplain biogeomorphology under these scenarios and climate change. The scenarios are driven by transitions in human value systems and they are color-coded: green (personalistic-consensual), orange (scientific-rational), and yellow (integrated-systemic). Per scenario, the landscaping measures were translated into a future topography and ecotope distribution. Using various spatially explicit simulation models, we evaluated the scenarios regarding the biogeomorphology in 2050: (1) flood peak reduction (green 0.11 , orange 0.65 , and yellow $0.37 \mathrm{~m}$ ), (2) year-average floodplain suspended sediment deposition $(+114,+148,+143 \%$ ), (3) food web exposure to heavy metals ( $4-5$ out of 10 species for all scenarios) and (4) biodiversity value $(+23,-4,+39 \%)$. We conclude that ( 1 ) analysis of value systems provides a broad interpretive framework for scenario development, which guides the choices for transitions and (2) the biogeomorphology is affected by climate change ( $+58 \%$ deposition), but the effects of the local landscaping measures are even stronger. None of the scenarios shows the ideal combination of high flood peak reduction, low sedimentation, and high biodiversity. Ecotoxicological risks seem less discriminative.
\end{abstract}

(c) 2009 Elsevier B.V. All rights reserved.

\section{Introduction}

Lowland floodplains play an important role as sinks of suspended sediments and pollutants (Meade, 1982), and have a key-role in ecological transformation processes along the river continuum from the upstream basin towards the estuary. Sediment accumulation rates on floodplains are spatially variable, associated with differences in flooding frequency, flood pattern and distance to the river channel (Allison et al., 1998; Walling and Owens, 2003). The pollutants, such as heavy metals, are incorporated in the ecological food-chain (Torres and Johnson, 2001). The hydrodynamics and

\footnotetext{
* Corresponding author. Now at: ITC, PO Box 6, 7500 AA, Enschede, The Netherlands. Tel.: +31 624967637; fax: +31 534874336 .

E-mail addresses: straatsma@itc.nl, m.straatsma@geo.uu.nl (M. Straatsma), a.schipper@science.ru.nl (A. Schipper), m.vanderperk@geo.uu.nl (M. van der Perk), duurzame@rivierkunde.nl (C. van den Brink), r.leuven@science.ru.nl (R. Leuven), h.middelkoop@geo.uu.nl (H. Middelkoop).
}

inundation frequency also influence the ecotope distribution (Deil, 2005), while the ecotope distribution in turn determines the potential biodiversity (De Nooij et al., 2004). Altogether, these and other studies revealed the complex biogeomorphological interactions that characterize these floodplain environments. This floodplain biogeomorphology has been affected by urban development and the rivers have been exploited because of their natural resources. In comparison to their natural situation, these river floodplains have a degraded ecological status and strongly altered hydrodynamics and geomorphology due to embankments, agriculture, buildings, infrastructure, and sediment excavation (Tockner and Stanford, 2002). In recent years, ecological restoration projects have been carried out in many countries (Buijse et al., 2002; Hillman and Brierley, 2005). Still, urban encroachment on rivers has caused further degradation of lowland river reaches and floodplains.

In the future, the biogeomorphological functioning of lowland floodplains is likely to be altered at an increased pace. The IPCC (2007) predicted an increased sea level rise, more rainfall at higher latitudes, and more extreme rainfall in Europe. Together with a 


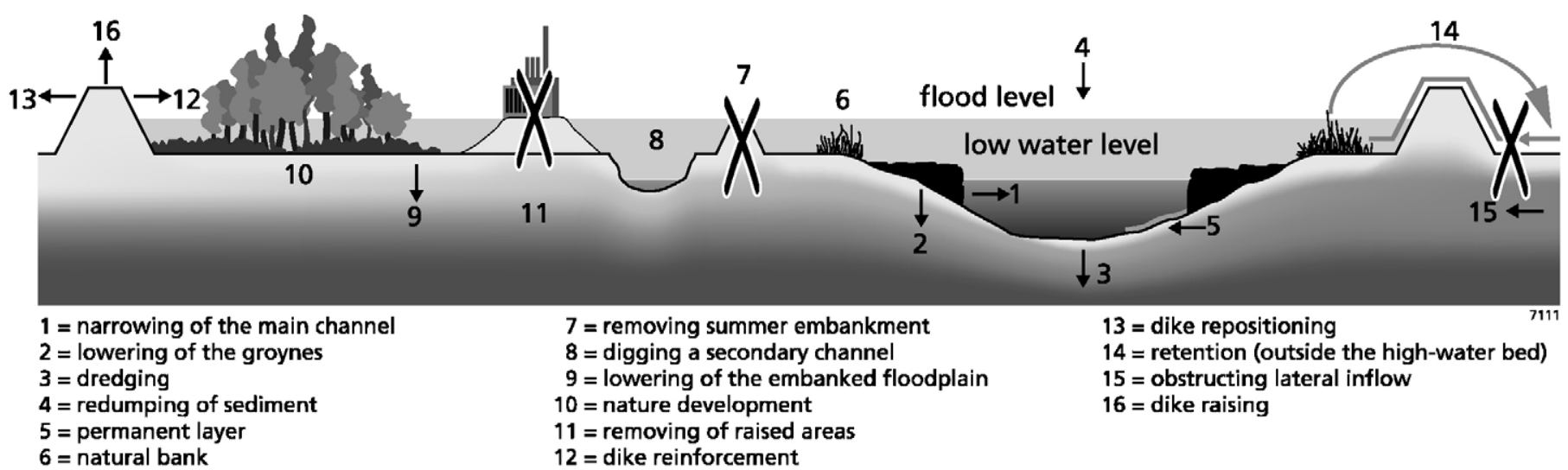

Fig. 1. Possible landscaping measures for flood hazard reduction, or nature development.

larger global population, these climatic changes are expected to increase the pressures on lowland rivers in developed areas. To cope with these pressures, integrated plans have been developed for several riverine areas in, e.g. Australia, North America, and Europe (Brierley and Fryirs, 2008; Klijn et al., 2008). These plans aim at harmonizing landscaping measures required to meet safety standards, for river health, shipping, housing, and recreation, with functions such as agriculture and the river corridor as a carrier of culturalhistoric values, which require preserving the status quo. Several landscaping measures have been proposed (Fig. 1) for reducing flood hazards and facilitating ecological rehabilitation. The choice and design of measures depend on the choices made in the decision making process, which in turn is strongly influenced by the value systems of the actors and society.

Planning of landscaping measures requires a long time horizon, from decades to centuries, as the implementation is time consuming and costly. Planning, therefore, involves scenario analysis to determine the feasibility and the effects of potential landscaping measures. Many methods exist for scenario development (e.g. Van Notten et al., 2003). For example, the IPCC (2000) used scenarios based on five drivers: population, economy, technology, energy, and land use. These drivers are combined into storylines for four scenarios that constitute a score on two axes: economicenvironmental and global-regional. However, the IPCC does not consider human values, which constitute an important foundation for long-term scenarios. Grumbine (1994) states that scientific knowledge should be integrated within a socio-political and values framework, because people base their commitments on values rather than on facts and logic. Therefore, scenarios for management should make the role of human values explicit (Grumbine, 1997). This applies to scenario development, in particular concerning river management in developed areas, where the landscape is largely man-made. Middelkoop et al. (2004) used Cultural Theory (Thompson et al., 1990) in a perspectives based scenario for water management of the lower Rhine, which considers values and value transitions expressed by 'world views' and associated 'management styles'. According to Cultural Theory, transitions in value systems can occur in all directions; this theory does not consider an order or sequence of the different perspectives on the world. Spi- ral Dynamcics (SD) (Beck and Cowan, 1996; Graves, 2006) provides an alternative model for value systems. SD gives a framework for a conceptual model of value systems that is hierarchic in nature, thereby limiting transitions to steps up or down the hierarchy. This makes that SD has an excellent potential for application in scenario development (Voros, 2006).

In this paper, we combined SD-based scenario development for river management with a quantification of the effects of the scenarios on floodplain biogeomorphology. We defined two goals, which we exemplify for the lower Rhine River in The Netherlands:

- Develop scenarios for 2050 based on shifts in the dominant value system in river management. Scenarios should facilitate the changing discharge regime and landscaping measures.

- Determine the spatially distributed effects of these scenarios on the biogeomorphology using existing spatially distributed simulation models.

In any scenario development, a number of arbitrary choices have to be made, and SD-based scenarios do not make an exception. However, by basing the selection of landscaping measures on value systems, the scenarios are internally coherent. The application of SD thus limits the arbitrariness of the scenarios. We constructed three scenarios, each of which was translated into a future topography and land use of the lower Rhine floodplains. Using spatially explicit simulation models, the scenarios were evaluated regarding four aspects of the biogeomorphology: (1) hydrodynamics, (2) deposition of sediment and associated heavy metals, (3) ecotoxicological risks of heavy metal contamination, and (4) potential biodiversity values.

\section{Methods}

\subsection{Scope}

The study focused on the lower Rhine floodplains. At the Dutch-German border, the River Rhine has an average discharge of $2250 \mathrm{~m}^{3} / \mathrm{s}$, draining a catchment area of $165,000 \mathrm{~km}^{2}$. The study area comprises the River Waal, which is the main distributary of the
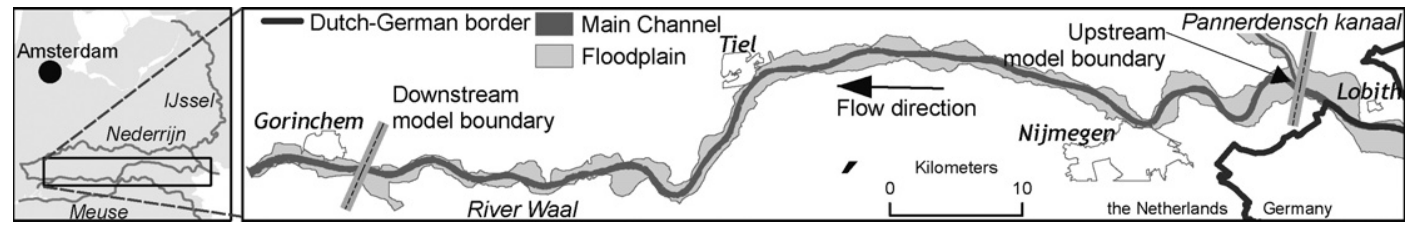

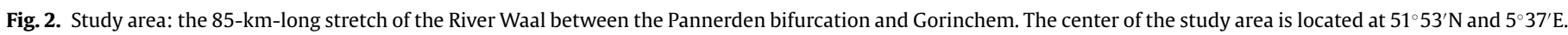




\section{a) Reference situation 2001}

a1 Ecotope distribution

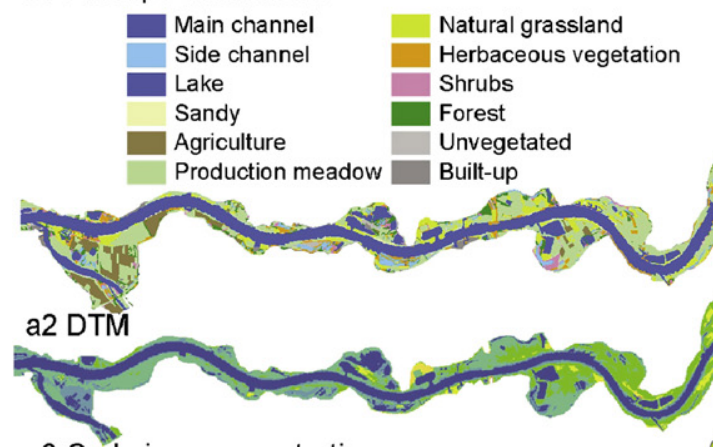

a3 Cadmium concentration
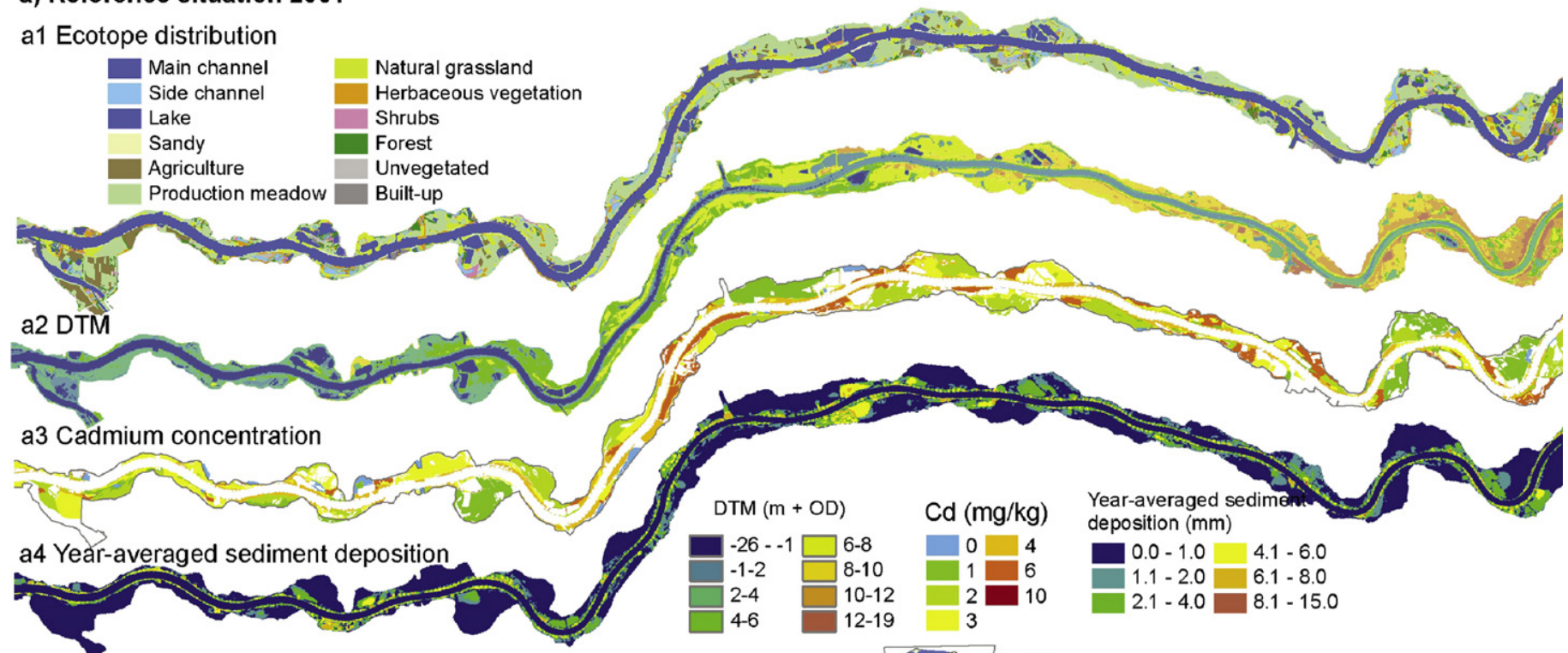

a4 Year-averaged sediment deposition

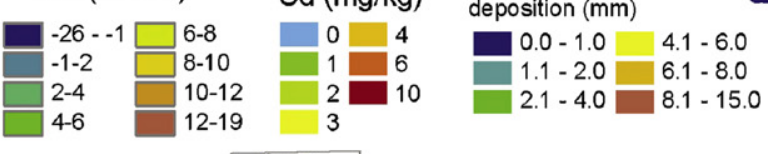

b) Landscaping measures for scenarios $\mathbf{2 0 5 0}$ $\square$ Floodplain — Primary side channe Floodplain height change $\square$ Dike repositioning b1 Green Special regions
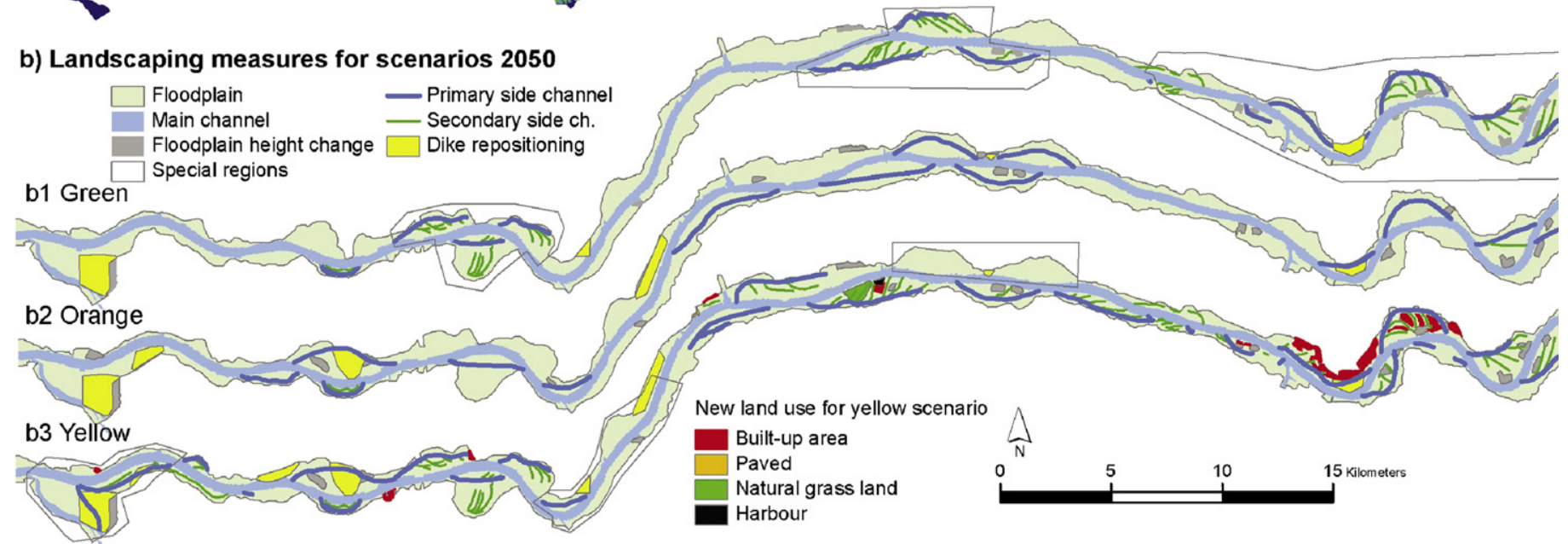

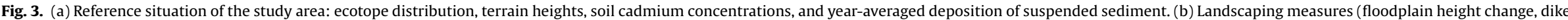

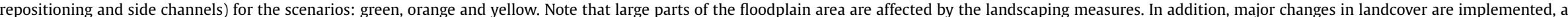
derived from the ecotope transition matrix (Table 4). 
River Rhine in the Netherlands (Fig. 2). The study area spans an 85$\mathrm{km}$-long river reach with an average water gradient of $0.10 \mathrm{~m} / \mathrm{km}$. The total area of the embanked floodplains amounts to $230 \mathrm{~km}^{2}$. The main channel is around $250-\mathrm{m}$ wide and fixed by groynes. The cross-sectional width between the primary embankments varies between 0.5 and $2.6 \mathrm{~km}$. Fig. 3a shows the topographic heights and ecotope distribution. Meadows dominate the land cover, but recent nature rehabilitation programs led to increased areas with herbaceous vegetation, shrubs and forest has increased. The total yearly suspended sediment load through the River Waal is 1.7 Mton. Deposition of suspended sediments on the floodplains amounts to $1.3 \mathrm{~mm} / \mathrm{y}$ on average (Asselman and van Wijngaarden, 2002). Over the past century the Rhine water and sediments have been strongly contaminated. Historic heavy metal pollution peaked in the $1920 \mathrm{~s}$ and 1960s (Middelkoop, 2002), which has left large amounts of heavy metals in the floodplain deposits.

We chose the year 2050 as projection year for the scenarios. This is a commonly used time horizon for climatic and hydrological scenario analyses (e.g. IPCC, 2007), as a more remote horizon becomes increasingly uncertain to consider. The Dutch meteorological institute KNMI developed four climate change scenarios for the Netherlands projected to the year 2050 (Van den Hurk et al., 2006). To determine the river discharge regime for 2050, we selected the so-called KNMI-W scenario. This scenario assumes a $2{ }^{\circ} \mathrm{C}$ increase in temperature and a weak change in atmospheric circulation, resulting in a change in precipitation of $+6 \%$ in winter and $-5 \%$ in summer, and an $8 \%$ increase in summer evaporation from 1990 to 2050. The KNMI-W scenario is less extreme than the KNMI$\mathrm{W}+$ scenario, which has higher extreme values for precipitation. Hydrological simulations based on climate change scenarios suggest an increased flooding probability for the Rhine as the regime will shift from a combined rain-fed/meltwater river into a mainly rain-fed river (Shabalova et al., 2003). The design discharge for flood protection structures, the discharge with a 1/1250 annual probability of exceedance, is currently determined at $15,000 \mathrm{~m}^{3} / \mathrm{s}$. The main Rhine distributaries should be capable of carrying $16,000 \mathrm{~m}^{3} / \mathrm{s}$ by the year 2015 (Silva et al., 2001).

For our scenario study, we chose a design discharge of $17,000 \mathrm{~m}^{3} / \mathrm{s}$ at Lobith for 2050 . To compensate for the $0.67 \mathrm{~m}$ increase in water levels, we only considered landscaping measures carried out within the study area. To facilitate comparison, the input of heavy metals and suspended sediment was kept equal in the three scenarios.

\subsection{Spiral Dynamics and scenario development}

To obtain coherent scenarios based on human values, we adopted Spiral Dynamics (SD) as conceptual model of value systems (Beck and Cowan, 1996; Graves, 2006). SD structures the evolution of human value systems in a color-coded double helix (Graves, 2006). One helix represents the life conditions, the other the mind-culture coping conditions (Fig. 4 and Table 1). Each stage of development on the spiral represents a value system, which is a container for methods, beliefs and opinions. The hierarchy in value systems does not involve a judgment. Each value system may have healthy and unhealthy expressions, and each may be the appropriate answer to specific life conditions. Nonetheless, the higher levels are more inclusive and complex. The spiral provides a map of different value systems, whereas the dynamics describe transitions up or down along the spiral. All value systems are potentially available to everybody. Depending on the situation, different values systems spring to life. The colors alternate between warm (beige, red, orange, and yellow) and cool (purple, blue, green, and turquoise). The warm colors represent the orientation on the individual, whereas the levels with the cool colors are oriented on the community.

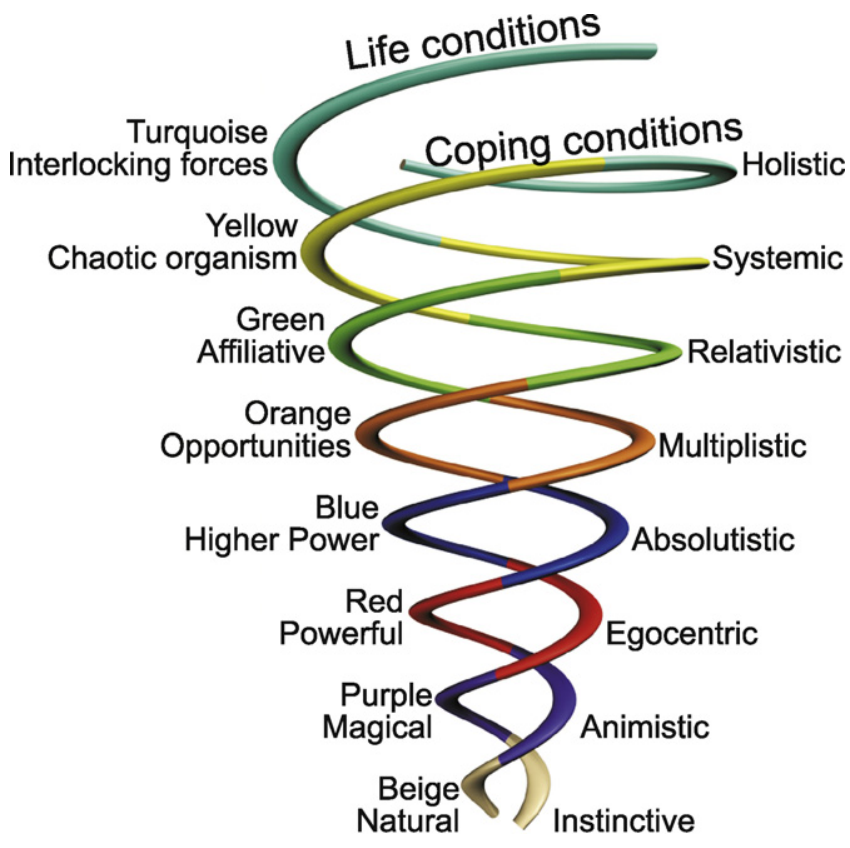

Fig. 4. The color-coded spiralling double helix of the biopsychosocial human development in Spiral Dynamics. One spiral represents the life conditions, the other the mind/coping capacities required for dealing with these life conditions. See Table 1 for details.

The current dominant value system in the Netherlands, with its consensual attitude and attention for ecology plus landscape diversity, can be considered 'green' (Straatsma and De Nooij, 2009). Hence, a green value system provides the logical starting point for the scenarios. Starting from the green value system, we propose three different scenarios that are likely given the possible dynamics in value systems in relation to the time horizon of 2050 . This means that shifts from green to, e.g. blue or turquoise are not considered realistic. Our scenarios are color-coded following SD colors:

1. Green: strengthening of the relativistic value system.

2. Orange: shifting to the multiplistic value system.

3. Yellow: shifting to the systemic value system.

Translation of these SD-based scenarios into specific spatial layouts of landscaping measures was done as follows: a workshop was organized bringing together 10 experts in river management, with backgrounds in ecology, hydraulics, cyclic floodplain rejuvenation, transition management, integrated river management and geomorphology. The workshop participants were given a presentation to clarify the mindset of people living with the different value systems. Subsequently, the participants agreed upon landscaping measures (Fig. 1) representative for the respective value systems and sketched these measures on an empty map of the study area. The green value system was translated in landscaping measures that could be the result of: consensus finding, equality between different groups, 'grass roots', and natural design. The orange value system was oriented towards low costs, blue print, engineering-dominated, water follows function, and low hydrodynamic roughness. The landscaping measures for the yellow scenario had to display adaptation in incorporating novel techniques, a big picture view, natural design, and win-win situations. Although such an approach does not prevent arbitrary choices, we assume that the arbitrariness is limited due to the application of a coherent framework for scenario development and the consensus obtained between 10 different experts.

The SD-based scenarios consist of narratives of how river management could be between 2009 and 2050 based on the 
Table 1

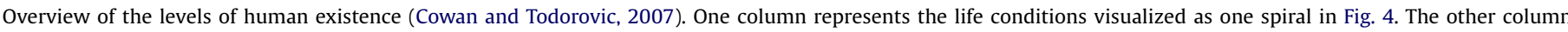
represents the coping conditions that are required for each set of life conditions. This is visualized as a second spiral in Fig. 4.

\begin{tabular}{|c|c|}
\hline Life conditions & Mind/culture coping conditions \\
\hline \multicolumn{2}{|l|}{ Turquoise } \\
\hline $\begin{array}{l}\text { A delicately balanced system of interlocking forces in jeopardy at } \\
\text { humanities hands }\end{array}$ & $\begin{array}{l}\text { Holistic: experiential: transpersonal; collective consciousness; } \\
\text { collaborative; interconnected }\end{array}$ \\
\hline \multicolumn{2}{|l|}{ Yellow } \\
\hline $\begin{array}{l}\text { A chaotic organism where change is the norm and uncertainty an } \\
\text { acceptable state of being }\end{array}$ & $\begin{array}{l}\text { Systemic: functional; integrative; interdependent; existential; flexible; } \\
\text { questioning; accepting }\end{array}$ \\
\hline \multicolumn{2}{|l|}{ Green } \\
\hline $\begin{array}{l}\text { The habitat wherein humanity can find love and purpose } \\
\text { through affiliation and sharing }\end{array}$ & $\begin{array}{l}\text { Relativistic; respond to human needs; affiliative; situational; consensual; } \\
\text { fluid }\end{array}$ \\
\hline \multicolumn{2}{|l|}{ Orange } \\
\hline $\begin{array}{l}\text { Full of resources to develop and opportunities to make things } \\
\text { better and bring prosperity }\end{array}$ & $\begin{array}{l}\text { Multiplistic: pragmatically to achieve results and get ahead; test options; } \\
\text { maneuver. }\end{array}$ \\
\hline \multicolumn{2}{|l|}{ Blue } \\
\hline $\begin{array}{l}\text { Controlled by a higher power that punishes evil and eventually } \\
\text { rewards good works and righteous living }\end{array}$ & $\begin{array}{l}\text { Absolutistic: obediently as higher authority and rules direct; conforming; } \\
\text { guilt }\end{array}$ \\
\hline \multicolumn{2}{|l|}{ Red } \\
\hline $\begin{array}{l}\text { Like a jungle where the tough and strong prevail and the weak } \\
\text { serve; nature is an adversary to be conquered }\end{array}$ & Egocentric: asserting self for dominance, conquest and power. Exploitive \\
\hline \multicolumn{2}{|l|}{ Purple } \\
\hline $\begin{array}{l}\text { Threatening and full of mysterious powers and spirits that must } \\
\text { be placated and appeased }\end{array}$ & Animistic: according to tradition and ritual ways of the group/tribe \\
\hline \multicolumn{2}{|l|}{ Beige } \\
\hline $\begin{array}{l}\text { State of nature and biological urges and drives: physical senses } \\
\text { dictate the state of being }\end{array}$ & Instinctive: as natural instincts and reflexes direct; automatic existence \\
\hline
\end{tabular}

Table 2

Overview of the scenarios based on green, orange and yellow river management.

\begin{tabular}{|c|c|c|}
\hline Value system & River management & Implementation \\
\hline \multicolumn{3}{|l|}{ Green } \\
\hline Living with the human element & Polder mentality, local communities have a say & Space for the river combined with ecological restoration \\
\hline Getting along with others & Focus on ecology & Solutions for individual floodplain sections \\
\hline \multirow[t]{2}{*}{ Consensual } & Dike raising is no option & Groyne lowering \\
\hline & & Cyclic floodplain rejuvenation \\
\hline \multicolumn{3}{|l|}{ Orange } \\
\hline Conquering the physical universe as to overcome want & Centralized authority & Dike raising \\
\hline Oriented at technology and competition & Cost-benefit analyses & Groyne lowering \\
\hline \multirow[t]{4}{*}{ Pragmatic } & Dike raising is a cheap option & Removal of hydraulic bottlenecks \\
\hline & & Removal of vegetation that obstructs flow \\
\hline & & Removal of minor embankments \\
\hline & & Retention areas \\
\hline \multicolumn{3}{|l|}{ Yellow } \\
\hline Restoring vision in a disordered world & Spatially coherent plan for the whole river section & Side channels follow the historic swale channels \\
\hline \multirow[t]{4}{*}{ Integrative } & Interactive & Cyclic floodplain rejuvenation \\
\hline & Local communities participate from the design phase & Local initiatives in line with the overall direction \\
\hline & Water as the guiding principle & Multi-purpose groyne lowering \\
\hline & Dike raising is an option when needed & \\
\hline
\end{tabular}

Table 3

Overview of scenario landscaping measures.

\begin{tabular}{|c|c|c|c|c|c|}
\hline Scenario & ETM $^{\mathrm{a}}$ & Side channels ${ }^{\mathrm{b}}$ & Floodplain height change & No. of dike repositioning & Barriers \\
\hline Green & $\begin{array}{l}\text { Within the regions } \\
\text { (Figs. } 3 \text { and } 8 \text { ) }\end{array}$ & $\begin{array}{l}\text { Within regions (17/64). } \\
\text { Pattern based on old swales } \\
\text { Gentle natural slopes }\end{array}$ & 32 lowered 0 raised & 3 & $\begin{array}{l}\text { Groyne lowering } 1 \mathrm{~m} \\
\text { Barrier removal within regions }\end{array}$ \\
\hline Orange & Everywhere & $\begin{array}{l}\text { Everywhere }(16 / 3) \\
\text { Pattern based on maximum } \\
\text { discharge capacity } \\
\text { Steep unvegetated slopes }\end{array}$ & $\begin{array}{l}51 \text { lowered } \\
0 \text { raised }\end{array}$ & 5 & $\begin{array}{l}\text { Groyne lowering } 1 \mathrm{~m} \\
\text { Barrier removal everywhere }\end{array}$ \\
\hline Yellow & $\begin{array}{l}\text { Outside of regions } \\
\text { (Figs. } 3 \text { and } 8 \text { ) }\end{array}$ & $\begin{array}{l}\text { Outside of regions (31/81) } \\
\text { Pattern based on old swales } \\
\text { Natural slopes }\end{array}$ & $\begin{array}{l}33 \text { lowered, } 19 \text { raised for new } \\
\text { residential areas }\end{array}$ & 7 & $\begin{array}{l}\text { Groyne lowering } 1 \mathrm{~m} \\
\text { Barrier removal outside regions }\end{array}$ \\
\hline
\end{tabular}

\footnotetext{
a ETM, ecotope transition matrix.

b The numbers in brackets indicate the numbers of primary and secondary side channels.
} 
Table 4

Ecotope transition matrix. The three columns on the left indicate name, class and code of the ecotopes. The three columns on the right show the transitions per scenario.

\begin{tabular}{|c|c|c|c|c|c|}
\hline Description $^{\mathrm{a}}$ & Aggregated ecotope class (Figs. 3 and 8; Table 9) & Reference & Green & Orange & Yellow \\
\hline High-water-free shrubs & Shrubs & RHb-2 & RHb-2 & $\mathrm{RHg}-3$ & RHb-2 \\
\hline High-water-free prod. forest & Forest & RHb-3 & RHb-1 & RHb-3 & $\mathrm{RHb}-3$ \\
\hline High-water-free prod. meadow & Production meadow & RHg-3 & RHg-1 & RHg-3 & $\mathrm{RHg}-3$ \\
\hline High-water-free unvegetated area & Unvegetated & RHk-1 & RHr-1 & RHk-1 & RHr-1 \\
\hline High-water-free herbs & Herbaceous vegetation & RHr-1 & RHr-1 & RHr-2 & RHr-1 \\
\hline High-water-free arable land & Agriculture & RHr-2 & RHb-1 & RHr-2 & RHb-1 \\
\hline High-water-free built-up area & Built-up area & $\mathrm{RHr}-3$ & $\mathrm{RHr}-3$ & RUk-1 & RHr-3 \\
\hline Marshy hardwood forest & Herbaceous vegetation & RMb-1 & RMb-1 & RMg-1 & RMb-1 \\
\hline Marshy softwood forest & Forest & RMb-2 & RMb-2 & $\mathrm{RMg}-2$ & RMb-2 \\
\hline Marshy softwood shrubs & Shrubs & RMb-3 & $\mathrm{RMb}-3$ & $\mathrm{RMr}-1$ & $\mathrm{RMb}-3$ \\
\hline Floodplain seepage forest & Forest & $\mathrm{RMb}-4$ & $\mathrm{RMb}-4$ & RMr-1 & $\mathrm{RMb}-4$ \\
\hline Marshy fl.pl. production meadow & Production meadow & RMg-2 & RMg-1 & $\mathrm{RMg}-2$ & RMg-1 \\
\hline Herbaceous swamp & Herbaceous vegetation & RMr-1 & $\mathrm{RMr}-1$ & $\mathrm{RMg}-2$ & RMr-1 \\
\hline Sedge swamp & Herbaceous vegetation & $\mathrm{RMr}-4$ & $\mathrm{RMr}-4$ & RMg-2 & $\mathrm{RMr}-4$ \\
\hline Natural levee hardwood shrubs & Shrubs & ROb-2 & ROb-2 & ROg-3 & ROb-2 \\
\hline Natural levee softwood forest & Forest & ROb-3 & ROb-3 & ROg-3 & ROb-3 \\
\hline Natural levee softwood shrubs & Shrubs & ROb-4 & ROb-4 & $\mathrm{ROg}-3$ & ROb-4 \\
\hline Natural levee production forest & Forest & ROb-5 & ROb-1 & ROb-5 & ROb-5 \\
\hline Natural levee production meadow & Production meadow & ROg-3 & ROg-1 & ROg-3 & ROg-1 \\
\hline Natural levee unvegetated area & Unvegetated & ROk-1 & ROg-1 & ROk-1 & ROg-1 \\
\hline Herbaceous natural levee & Herbaceous vegetation & ROr-2 & ROr-2 & ROg-3 & ROr-2 \\
\hline Natural levee arable land & Agriculture & ROr-3 & ROb-2 & ROr-3 & ROb-2 \\
\hline Floodplain hardwood shrubs & Shrubs & RUb-2 & RUb-2 & RUg-3 & RUb-2 \\
\hline Floodplain softwood forest & Forest & RUb-3 & RUb-3 & RUg-3 & RUb-3 \\
\hline Floodplain softwood shrubs & Shrubs & RUb-4 & RUb-4 & RUg-3 & RUb-4 \\
\hline Floodplain hardwood production forest & Forest & RUb-5 & RUb-1 & RUb-5 & RUb-5 \\
\hline Floodplain production meadow & Production meadow & RUg-3 & RUg-1 & RUg-3 & RUg-1 \\
\hline Floodplain unvegetated area & Unvegetated & RUk-1 & RUr-1 & RUk-1 & RUr-1 \\
\hline Rich structured herbaceous & Herbaceous vegetation & RUr-1 & RUr-1 & RUg-3 & RUr-1 \\
\hline Poor structured herbaceous & Herbaceous vegetation & RUr-2 & RUr-2 & RUg-3 & RUr-2 \\
\hline Floodplain arable land & Agriculture & RUr-3 & RUb-2 & RUr-3 & RUb-2 \\
\hline
\end{tabular}

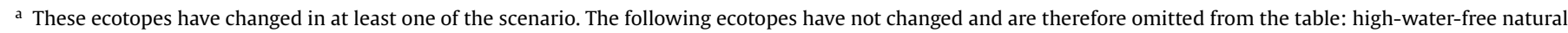

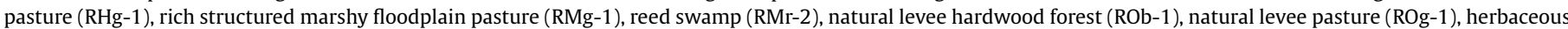

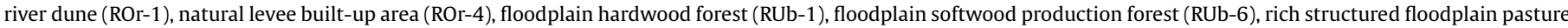

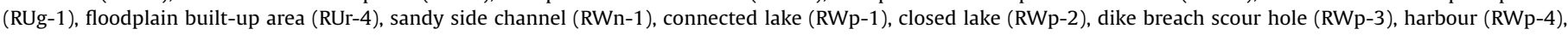
connected floodplain channel (RWs-1), closed floodplain channel (RWs-2), summer bed (RZd-1), shallow sand bed (RZo2), sandy beach (RZs-2), clayey beach (RZs-3).

changes in value system. In addition, landscaping measures that have currently been approved by the Key decision on spatial planning of Room for the Rivers of the Dutch government (PKB; Anonymous, 2007) were implemented in each scenario. Tables 2 and 3 summarize the value systems in river management and their implementation. The resulting scenario layouts of the floodplains were implemented in a geographical information system (GIS) to provide primary, spatially explicit model input. The details of the GIS implementation are given in the section on model input.

\subsubsection{Green scenario}

Strengthening of the current green value system means a strong emphasis on consensus building based on the ability to truly establish a human connection between the different stakeholders in which people feel seen. When the connection fails, stakeholders become uncooperative and the projects get bogged down. However, consensus is difficult to attain when a large range of interests is at stake and the feeling of belonging to the community is not strong enough. Therefore, much time is needed to attain consensus con- cerning large-scale landscaping measures that combine safety and economic growth with river health, a sense of identity for humans, and recreation. This may be seen as the unhealthy aspect of the green value system.

Because of the constrained stakeholder cooperation, a complete spatial coverage of projects will not be ready in 2050. Therefore, measures have been implemented only in three regions where consensus has been reached (Fig. 3b1 and Table 3). Here, the method of cyclic floodplain rejuvenation is applied (Baptist et al., 2004). Ecotopes transition to natural vegetation, reflected in an increase in herbaceous vegetation and natural pasture and forest. Table 4 gives the ecotope transition matrix (ETM). To improve discharge capacity, 32 hydraulic bottlenecks like former brick factories and minor embankments have been removed (Table 3). Dikes have been repositioned at three critical locations and groynes have been lowered, since it requires only one stakeholder to persuade and consensus is easily found. Side channel beds are narrow (Table 5 and Fig. $5 ; w 1$ ) and connect to the main channel on the downstream end, mimicking a natural pointbar channel. The banks have gentle slopes (1:30), resulting in large overall widths (w2). Even at low water levels, the

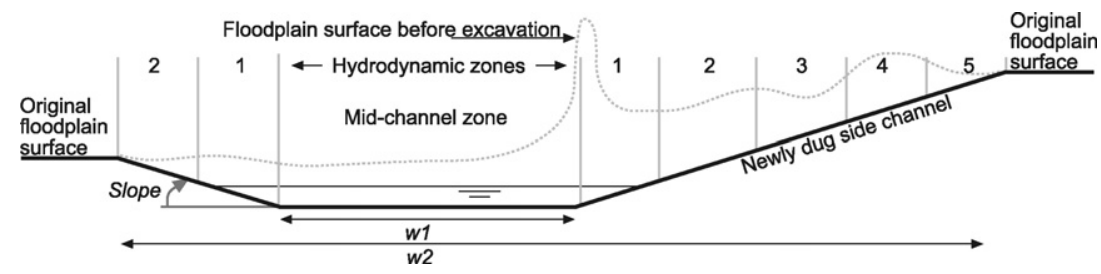

Fig. 5. General layout of primary and secondary side channels. Specific dimensions for the different scenarios can be found in Table 5 . 
Table 5

Dimensions of side channels (secondary side channels in brackets) for each scenario. An explanation of the parameters is given in Fig. 6 .

\begin{tabular}{lrlll}
\hline & $w 1^{\mathrm{a}}(\mathrm{m})$ & $w 2^{\mathrm{b}}(\mathrm{m})$ & Height $^{\mathrm{c}}(\mathrm{m}+\mathrm{OD})$ & Bank slope $(-)$ \\
\hline Green & $40(20)$ & $250(120)$ & $H_{345}-1 \mathrm{~m}\left(H_{215}\right)$ & $1: 30$ \\
Orange & $100(20)$ & $180(120)$ & $H_{345}-1.5-\mathrm{m}\left(H_{215}\right)$ & $1: 7$ \\
Yellow & $40(20)$ & $240(120)$ & $H_{345}-1.5 \mathrm{~m}\left(H_{215}\right)$ & $1: 12.5$ \\
\hline
\end{tabular}

a Width of the horizontal part of the cross-section.

b Maximum width of the side channel. True width depends on the current height of the floodplain.

${ }^{c} H_{345}$ is the water surface resulting from the discharge that is exceeded 345 days per year $\left(750 \mathrm{~m}^{3} / \mathrm{s}\right.$ at Lobith), $H_{215}$ the water surface exceeded $215 \mathrm{~d} / \mathrm{y}$. Height is relative to ordnance datum (OD).

primary side channels are at least 1-m deep, following the guidelines for the implementation of ecological measures along rivers (Wolters et al., 2002). Ecotopes on the banks are natural and in climax situation, with floodplain forest on the higher parts (Table 6 and Fig. 5).

\subsubsection{Orange scenario}

Shifting to the orange value system means a step backward on the spiral, to domination of the scientific-rational drive, focused at efficiency and outsmarting physical threats by implementing technological solutions. The orange scenario may be appropriate in case of increased pressure from climate change or social-economic stress. A pressing motive for this scenario may be a dike breach with a high number of human casualties, which will lead to an immediate call for safety, or an economical collapse resulting in a shortage of money for river management.

This scenario breaks with the current trend of more integrated river management and focuses on the key river functions: navigation and protection against flooding. In orange river management, the national government has retaken authority and has implemented a top-down management with measures applied within the entire study area. Cheap and efficient measures have been chosen, based on tried and tested technology. Groyne lowering $(1 \mathrm{~m})$ has been combined with dike raising. Minor embankments and fences have been removed, as this is a cheap option. Ecotope transitions focused on agricultural production and hydrodynamical smoothness (Tables 4 and 6). Shrubs and forests are only allowed in areas of low flow velocities. The new side channels are deep, have steep unvegetated banks, and connect to the main channel on both ends to maximize the discharge capacity.

\subsubsection{Yellow scenario}

A shift from the green to the yellow value system implies a master plan with a large public support in the fluvial area. Such a spatially coherent plan has been developed at the scale of the river reach in order to integrate the diverse functions and characteristics of the river, including hydraulics, geomorphology, ecology, housing, and landscape architecture. At the same time legislative limitations are overcome if they are unjust and put the project to a disadvantage. The comprehensive plans are based on sound scien- tific work and take uncertainty as a fundamental fact. Both historic maps and current natural rivers provide inspiration for measures. Novel building techniques are implemented to enable multiple use of space. All stakeholders are invited to participate from the starting phase, which has been characterized as interactive river management by Van Ast (2000). Nonetheless, unpopular measures will be taken if necessary. The basis for this scenario has been provided by the "Waalweelde" project. Waalweelde, meaning "Wealth along the River Waal,' provides an integral vision for the River Waal, which aims at (1) making the Waal more beautiful, (2) reducing the exceedance levels and (3) providing opportunities for spatial development (Braakhekke, 2007).

Contrary to the other scenarios, built-up areas have been developed at locations where cities need expansion, for example in the Nijmegen area, where population pressure is high. Three regions have been assigned with a focus on agricultural production (Fig. 3b3). The groynes in the yellow scenario have been adjusted using the concept of the 'island' groyne (Van Heereveld et al., 2007). This is a multi-purpose design, combining fish habitat improvement with reduction of peak water levels. Ecologically, the groyne area is classified as sandy side channel; hydraulically, it has been treated identically to the groyne areas in the other scenarios. Minor embankments have been removed everywhere except for areas with agricultural production. Side channels have moderately gentle slopes and naturally vegetated banks. They connect to the main channel on the downstream end, as in the green scenario. The ecotopes transition to natural types, but very rough ecotopes are avoided (Table 4).

\subsection{Floodplain biogeomorphology models}

To quantify the effects of the three scenarios on the biogeomorphology of the River Waal floodplains and compare these to the reference situation, we used spatially explicit simulation models, which were all calibrated and validated in earlier studies. We broke down the assessment into the following stepwise approach (Fig. 6):

1. Computation of the hydrodynamics using the WAQUA-model (RWS, 2007).

2. Computation of the year-average deposition of sediment and heavy metals using the SEDIFLUX-model (Middelkoop and Van der Perk, 1998).

3. Assessment of the potential ecotoxicological risk of heavy metal contamination using a simplified version of the SpaCE model (Schipper et al., 2008a,b).

4. Evaluation of the potential values for protected and endangered flora and fauna species using BIO-SAFE (Lenders et al., 2001; De Nooij et al., 2004).

\subsubsection{Primary model input}

The primary model input consisted of the topography, ecotope distribution and a soil map (Fig. 6). The Digital Terrain Model (DTM) (Fig. 3a2) was based on height information originating from echo soundings in the main river, airborne laser scanning, photogram-

Table 6

Assignment of ecotope codes per scenario for new side channels and lowered floodplains ${ }^{\mathrm{a}}$.

\begin{tabular}{|c|c|c|c|c|c|c|c|c|c|c|}
\hline \multirow[t]{3}{*}{ Scenarios } & \multicolumn{6}{|l|}{ Side channels } & \multirow{2}{*}{\multicolumn{4}{|c|}{$\begin{array}{l}\text { Floodplain lowering } \\
\text { Hydrodynamic zones }\end{array}$}} \\
\hline & \multirow[t]{2}{*}{ Mid-channel zone } & \multicolumn{5}{|c|}{ Hydrodynamic zones } & & & & \\
\hline & & 1 & 2 & 3 & 4 & 5 & 2 & 3 & 4 & 5 \\
\hline Green & RWn-1 & RWn-1 & RZs-2 & RMr-1 & ROb-3 & ROb-4 & RMr-1 & RMr-1 & RUr-1 & RUr-1 \\
\hline Orange & RWn-1 & RWn-1 & $\mathrm{RZs}-2$ & ROk-1 & RUk-1 & RUk-1 & RMg-1 & $\mathrm{RMg}-2$ & RUg-3 & RUg-3 \\
\hline Yellow & RWn-1 & RWn-1 & RZs-2 & RMr-1 & ROr-2 & ROb-3 & RMr-1 & RMr-1 & RUr-1 & RUr-1 \\
\hline
\end{tabular}

\footnotetext{
${ }^{\text {a }}$ Codes following the River Ecotope System (Table 4).
} 


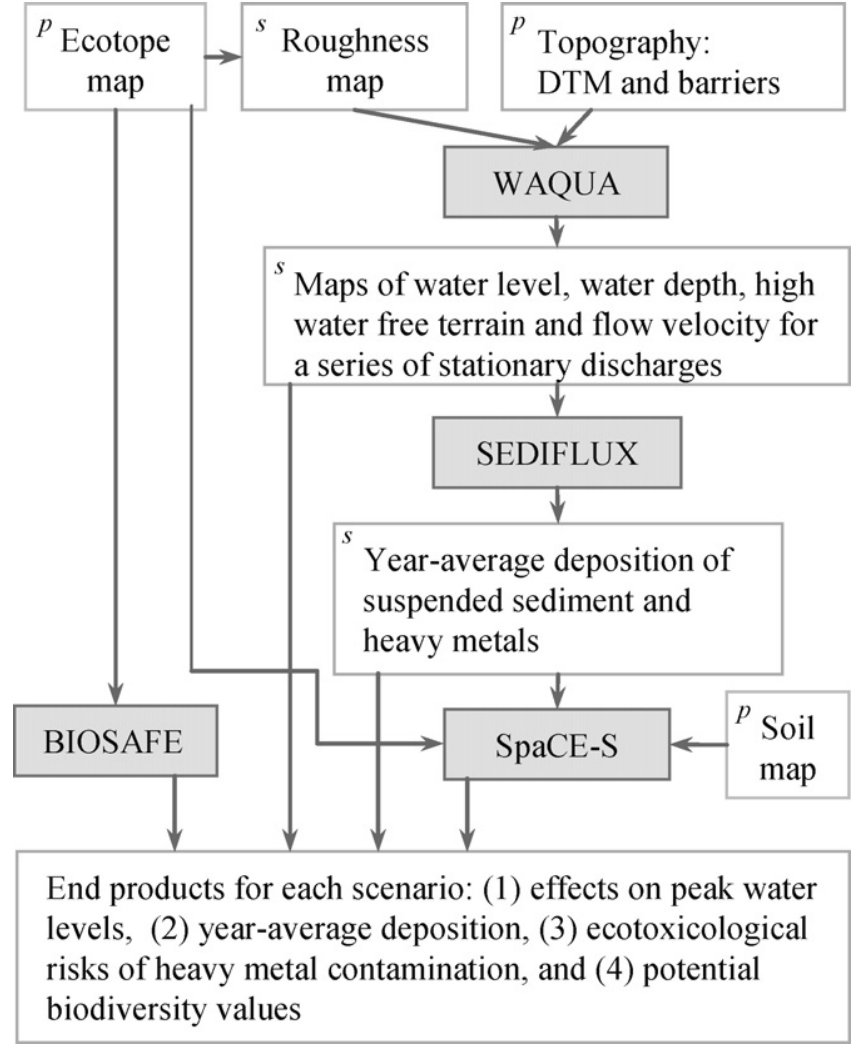

Fig. 6. Flow chart of the modeling scheme. Primary model input is indicated with a ' $p$ ', secondary input with an 's'.

metry, and terrestrial measurements of the floodplain surface (Van de Pas, 2005). These data were converted to point heights for model input. Summer embankments, groynes and terrain steps, which lead to additional energy losses for flowing water, were implemented as a separate input layer of lines with attributes describing the heights of the top and bottom of these so-called barriers. To implement landscaping measures affecting floodplain topography, height attributes of relevant point and line elements were accordingly adapted.

Lowered floodplain areas were given a height similar to that of the surroundings. Raised floodplain areas were given a height above the peak water level. Side channels differ between the scenarios in their cross-sectional depth and width, associated inundation fre- quency, bank slope profile and vegetation distribution on the banks (Fig. 5). The depth of the side channels was determined relative to the water level that is exceeded for $345 \mathrm{~d} / \mathrm{y}$ for primary side channels $\left(H_{345}\right)$ and $215 \mathrm{~d} / \mathrm{y}\left(\mathrm{H}_{215}\right)$ for secondary channels. Mid-channel zone width $(w 1)$ was set, whereas the overall channel width ( $w 2)$ varied according to the depth of the channel relative to the floodplain height. Dike repositioning was implemented by assigning an average height to the new floodplain area and placing a new line element at the position of the new dike.

The ecotope distribution is based on the floodplain ecotope map scale 1:10,000, which is classified according to the River Ecotope System (RES) (Jansen and Backx, 1998) (Fig. 3a1). RES uses a hierarchic structure of ecotopes based on the erosion and deposition rates, inundation frequency and management. In the ETM, that represented the value system, not all ecotopes were changed for all scenarios, to avoid unrealistically homogeneous ecotope distributions. The ecotopes on the side channel banks were representative for the local hydrodynamics, but differ between scenarios. The midchannel zone was always assigned the ecotope 'sandy channel,' reflecting the high flow velocity. The new floodplain areas resulting from the dike repositioning also got a value-based ecotope.

Soil cadmium concentration is derived from the soil map, scale $1: 25,000$. This map contains the distribution of several heavy metals in the top soil of the floodplain area (Hin et al., 2001) (Fig. 3a3).

\subsubsection{WAQUA-model}

The WAQUA-model is used by the Dutch Ministry of Transport, Public Works and Water Management for the two-dimensional simulation of hydrodynamics in the complex channel and floodplain areas of the Rivers Rhine and Meuse in the Netherlands (RWS, 2007). The model is based on a curvi-linear grid with cell length of approximately $40 \mathrm{~m}$ and a cell width varying between $15 \mathrm{~m}$ in the main channel and about $30 \mathrm{~m}$ in the distal floodplain areas. Input data from which the WAQUA-model calculates the water flow field are a DTM, and maps with hydraulic barriers and roughness exerted by the ground surface and vegetation. Floodplain roughness was determined from the ecotope map using a lookup table provided in the BASELINE 3.31 dataset (Van de Pas, 2005). We ran WAQUA for a series of stationary discharges between 3500 and $17,000 \mathrm{~m}^{3} / \mathrm{s}$ at Lobith (Table 7). At lower discharges, the floodplains are not inundated. The discharge frequencies for the reference situation (Table 7) were derived from the historic discharges at Lobith spanning 107 years between 1901 and 2007. For 2050, the adapted discharge frequencies were calculated for the KNMI-W climate scenario following the methodology presented in Thonon (2006).

Table 7

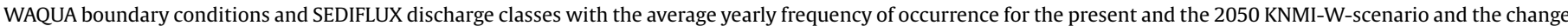
in between.

\begin{tabular}{|c|c|c|c|c|c|}
\hline Discharge class for Lobith $\left(\mathrm{m}^{3} / \mathrm{s}\right)$ & $\begin{array}{l}\text { Water level at downstream } \\
\text { model boundary }(\mathrm{m})\end{array}$ & Class range $\left(\mathrm{m}^{3} / \mathrm{s}\right)$ & Frequency 1901-2007 (d/y) & Frequency 2050 (d/y) & Change (\%) \\
\hline 3,500 & 0.91 & $3,250-3,750$ & 15.9 & 23.7 & 33 \\
\hline 4,000 & 1.04 & $3,750-4,250$ & 10.8 & 13.2 & 18 \\
\hline 4,500 & 1.17 & $4,250-4,750$ & 6.8 & 9.7 & 30 \\
\hline 5,000 & 1.29 & $4,750-5,250$ & 4.6 & 6.3 & 27 \\
\hline 5,500 & 1.44 & $5,250-5,750$ & 3.4 & 4.5 & 24 \\
\hline 6,000 & 1.59 & $5,750-6,250$ & 2.3 & 3.4 & 33 \\
\hline 6,500 & 1.75 & $6,250-6,750$ & 1.4 & 2.6 & 44 \\
\hline 7,000 & 1.89 & $6,750-7,500$ & 1.6 & 2.3 & 31 \\
\hline 8,000 & 2.14 & $7,500-8,500$ & 0.9 & 1.8 & 52 \\
\hline 9,000 & 2.36 & $8,500-9,500$ & 0.4 & 0.8 & 47 \\
\hline 10,000 & 2.62 & $9,500-11,000$ & 0.2 & 0.5 & 58 \\
\hline 12,000 & 3.12 & $11,000-13,000$ & 0.1 & 0.2 & 60 \\
\hline 14,000 & 3.76 & $13,000-15,000$ & 0.0 & 0.0 & NA \\
\hline 16,000 & 4.40 & $15,000-16,500$ & 0.0 & 0.0 & NA \\
\hline 17,000 & 4.75 & $16,500-17,500$ & 0.0 & 0.0 & NA \\
\hline
\end{tabular}




\subsubsection{SEDIFLUX-model}

The SEDIFLUX-model is a GIS-embedded sediment transport and deposition model, which was developed, calibrated and validated by Middelkoop and Van der Perk (1998). The model was revised to enable the use of the WAQUA curvi-linear grid maps of depth-averaged flow velocities in orthogonal directions and water depth as main input. The upstream boundary condition consists of a fixed suspended sediment concentration. To calculate the 2001 reference deposition rates, for each discharge the suspended sediment concentration at the upper model boundary was estimated using a sediment rating curve derived for the 1970-2006 period. For the 2050 scenario calculations, we adopted the sediment rating curve estimated by Thonon (2006):

$C_{2050}=25.5+1.96 \times 10^{-6} Q^{1.89}$

where $C_{2050}$ is the suspended sediment concentration estimated for $2050(\mathrm{mg} / \mathrm{l})$ and $Q$ the discharge at Lobith $\left(\mathrm{m}^{3} / \mathrm{s}\right)$.

The year-averaged sediment deposition $\left(\mathrm{kg} / \mathrm{m}^{2} / \mathrm{y}\right)$ was computed by summation of the vertical sediment deposition fluxes per discharge multiplied by the average annual number of days that the corresponding discharge classes occurred (Table 7). The deposition rates in $\mathrm{kg} / \mathrm{m} / \mathrm{y}$ were converted to $\mathrm{mm} / \mathrm{y}$ assuming a dry bulk sediment density of $1500 \mathrm{~kg} / \mathrm{m}^{3}$.

The annual deposition rate of cadmium (Cd) was calculated by totalizing the cadmium concentration for each discharge multiplied by the discharge-specific sediment deposition rate and frequency of occurrence (Table 7). The Cd concentration for each discharge was calculated using the Cd rating curve reported by Thonon (2006) with a correction factor for the difference between mean $\mathrm{Cd}$ concentration in suspended sediment at Lobith $(0.88 \mathrm{mg} / \mathrm{kg})$ and the mean Cd of freshly deposited sediment in the floodplains along the Rhine River (3.0 mg/kg; Middelkoop et al., 2003):

$[C d]=\gamma\left[0.57+\frac{2040}{Q}\right]$

where $[\mathrm{Cd}]$ is the cadmium concentration in the suspended sediment $(\mathrm{mg} / \mathrm{kg})$ and $\gamma$ a correction factor (3.4). The yearly $\mathrm{Cd}$ deposition rate and the average $\mathrm{Cd}$ concentration in the freshly deposited sediment (i.e. the $\mathrm{Cd}$ deposition rate divided by the sediment deposition rate) were calculated for both the reference situation and the scenarios. In the scenario calculations we assumed that the $\mathrm{Cd}$ rating curve did not change compared to the reference situation.

\subsubsection{The SpaCE-S model}

The SpaCE-model (Spatially explicit Cumulative Exposure model) quantifies the potential toxicological risks for terrestrial wildlife foraging in contaminated areas (Schipper et al., 2008a,b). We implemented a simplified version in a GIS environment, called SpaCE-S. At a $10 \mathrm{~m} \times 10 \mathrm{~m}$ spatial resolution, SpaCE-S computes the predicted exposure concentration (PEC) of Cd for 10 terrestrial vertebrate species, which constitute a food web. In addition to the species data, the model requires spatially distributed data concerning ecotopes, high water free areas and soil cadmium concentrations. The high water free areas are located where the DTM is higher than the water level resulting from a discharge exceeded $2 \mathrm{~d} / \mathrm{y}$. For the reference situation, the $2 \mathrm{~d} / \mathrm{y}$ discharge is $7200 \mathrm{~m}^{3} / \mathrm{s}$ at Lobith; for the scenarios it is $8200 \mathrm{~m}^{3} / \mathrm{s}$ (Fig. 7). For the computation of the soil $\mathrm{Cd}$ concentrations we assumed that each year the new, freshly deposited sediment is mixed with the top $10 \mathrm{~cm}$ of the floodplain soil due to bioturbation (Wijnhoven et al., 2006). The initial soil Cd concentrations for the reference situation were derived from the soil map. For the scenarios, a Cd concentration of $0.53 \mathrm{mg} / \mathrm{kg}$ was assigned to new floodplain areas resulting from dike repositioning. This concentration corresponds to the average top soil concentration in fluvial clays of embanked areas in the

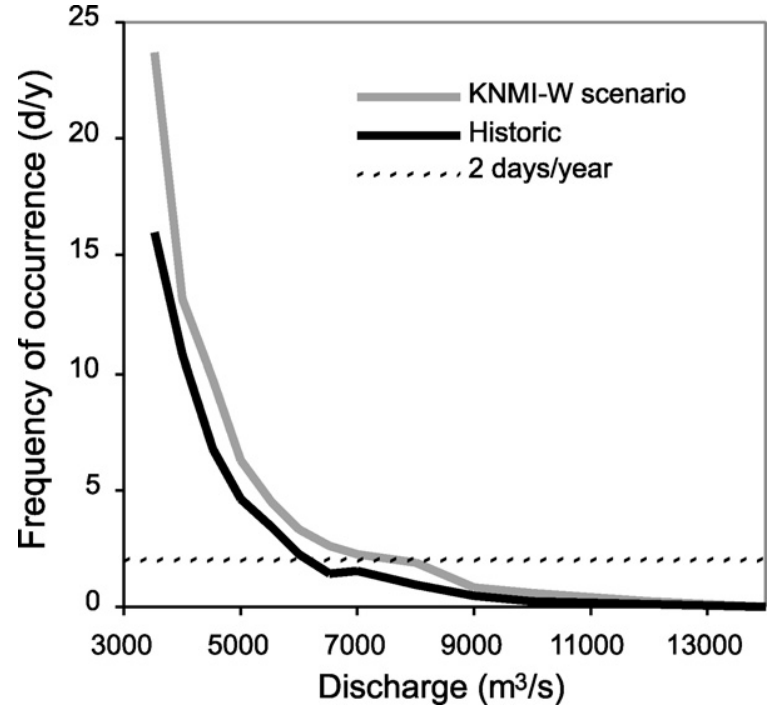

Fig. 7. Frequency of occurrence of discharge at Lobith over the period 1901-2007 and in 2050 according to the KNMI-W-scenario in $500 \mathrm{~m}^{3} / \mathrm{s}$ steps.

Netherlands (Van der Veer, 2006). The soil concentrations rendered by floodplain lowering projects depend on the excavation depths and the historic sedimentation rates. Because three-dimensional information on soil quality was not available, we assigned a Cd concentration of $3 \mathrm{mg} / \mathrm{kg}$ to the excavated areas, which corresponds to the average $\mathrm{Cd}$ concentration of recent River Waal deposits.

\subsubsection{BIO-SAFE}

BIO-SAFE is a model for quantification of (potential) values of riverine landscapes for protected and endangered species characteristic for river floodplain systems, depending on ecotope distribution, and weighting criteria based on policy and environmental law. Lenders et al. (2001) and De Nooij et al. (2006) describe the model setup, validation and a sensitivity analysis. The model was developed for the floodplains of the Rivers Rhine and the Meuse in the Netherlands, Germany, France and Belgium and is based on policy and legal criteria (De Nooij et al., 2004). For the present study only a few functions of BIO-SAFE were used. The Taxonomic group Floodplain Importance score (TFI) was computed for six taxonomic groups based on the ecotope maps of the reference situation and the scenarios. High TFI values represent a high (potential) biodiversity value.

\section{Results}

\subsection{Biogeomorphological functioning}

In this section, we present the modeling results for the reference situation with the current discharge regime (REF2001), the reference situation with the KNMI-W discharge regime for 2050 (REF2050), and the value-based scenarios with the KNMI-W discharge regime for 2050 (Table 8).

\subsubsection{Ecotope distribution and biodiversity value}

The ecotope distributions resulting from the ETM and the landscaping measures for the scenarios are shown in Fig. 8a. Note the difference in land use in the regions for the green and yellow scenario and the dominance of production meadow in the orange scenario. The summary statistics for groups of ecotopes are given in Table 9, and visualized in Fig. 9. For example, production meadow takes up $29 \%$ in the reference situation. In the green and yellow 
Table 8

Summary of modeling results.

\begin{tabular}{|c|c|c|c|c|c|}
\hline & REF2001 & REF2050 & Green & Orange & Yellow \\
\hline $\begin{array}{l}\text { Average lowering of peak water level at } \\
17,000 \mathrm{~m}^{3} / \mathrm{s}(\mathrm{m})\end{array}$ & NA & NA & 0.11 & 0.65 & 0.37 \\
\hline $\begin{array}{l}\text { River length requiring additional } \\
\text { lowering of water level or dike } \\
\text { raising }(\mathrm{km})\end{array}$ & 85 & 85 & 85 & 41 & 84 \\
\hline High water free surface area $\left(\mathrm{km}^{2}\right)$ & 12.4 & 8.7 & 8.2 & 9.8 & 9.7 \\
\hline $\begin{array}{l}\text { Sediment deposition in groyne area } \\
(\mathrm{mm})\end{array}$ & 3.61 & 5.06 & 3.56 & 4.33 & 3.68 \\
\hline $\begin{array}{l}\text { Year-averaged sedimentation on } \\
\text { floodplain }(\mathrm{mm})\end{array}$ & 1.15 & $1.81(+58 \%)$ & $2.44(+112 \%)$ & $2.85(+148 \%)$ & $2.80(+143 \%)$ \\
\hline $\begin{array}{l}\text { Total deposition of sediment }\left(10^{6} \mathrm{~kg} / \mathrm{y}\right) \\
(\mathrm{Cd}(\mathrm{kg} / \mathrm{y}))\end{array}$ & $199(655)$ & 306 (989) & 358 (1157) & $422(1372)$ & 406 (1329) \\
\hline $\begin{array}{l}\text { Percentage of total flux deposited at } \\
\qquad Q>3500 \mathrm{~m}^{3} / \mathrm{s}(-)\end{array}$ & 26 & 27 & 31 & 37 & 35 \\
\hline $\begin{array}{l}\text { Average cadmium concentration in } \\
\text { floodplain soil }(\mathrm{mg} / \mathrm{kg})\end{array}$ & 2.74 & 2.74 & 2.95 & 3.01 & 3.04 \\
\hline $\begin{array}{l}\text { No. of species for which } \mathrm{PEC}_{\mathrm{Cd}}>\mathrm{PNEC}_{\mathrm{Cd}} \\
\text { (cumulative affected fraction of } \\
\text { habitat) }\end{array}$ & $5(39 \%)$ & $5(39 \%)$ & $4(37 \%)$ & $5(40 \%)$ & $4(37 \%)$ \\
\hline Relative BIO-SAFE scores & 1 & 1 & 1.23 & 0.96 & 1.39 \\
\hline
\end{tabular}

scenario, it decreases by 14.8 and $21.9 \%$ respectively, whereas in the orange scenario it raises by $8.2 \%$. Calculations of TFIy scores with BIO-SAFE show an increase in the potential biodiversity values of the river landscape for the yellow and green river management strategies in comparison with the reference situation (Fig. 10). The increase in potential biodiversity values is caused by expanding the acreage of the ecotopes side channels, natural grassland and herbaceous vegetation at the expense of production meadows and agriculture. The orange strategy yields a decrease in potential biodiversity for most taxonomic groups (except mammals and fish). This is mainly due to a decrease in surface area of the ecotopes natural grassland, herbaceous vegetation, shrubs and forest and strong expansion of production grasslands. So, based on potential values of the riverine landscape for protected and endangered species, the ranks of the management strategies show the following order: yellow $>$ green $>$ orange (Table 9 and Figs. 8-10).

\subsubsection{Hydrodynamics}

The landscaping measures strongly affect the flow patterns and peak water levels. The average water level reductions along the river axis at a $17,000 \mathrm{~m}^{3} / \mathrm{s}$ discharge are $0.11 \mathrm{~m}$ in the green, $0.65 \mathrm{~m}$ in the orange, and $0.37 \mathrm{~m}$ in the yellow scenario. The highest reduction in water level is achieved in the upstream part of the River Waal (Fig. 11). The difference in water level between 17,000 and $15,000 \mathrm{~m}^{3} / \mathrm{s}$ is around $0.67 \mathrm{~m}$ over the whole study area. Therefore, the implemented landscaping measures do not compensate for the expected increase in water level, and additional measures are required, especially in the downstream part. The orange scenario adequately reduces the peak water level over the first $44 \mathrm{~km}$ on the upstream end, rendering additional measures unnecessary there. The green and yellow scenario need additional measures over the whole study area. Different ecotopes and side channel bank vegetation have a clear influence on the flow pattern. The water flow velocities in the floodplains are higher for the orange scenario than for the green scenario, where the floodplains forests along the side channels block the water flow. Groyne lowering gives a small increase in flow velocity in the groyne field, varying between $0.01 \mathrm{~m} / \mathrm{s}$ for the yellow scenario and of $0.03 \mathrm{~m} / \mathrm{s}$ for the green scenario. Due to the larger discharge capacity of the river in the orange scenario, the surface area of the high water free terrain (at $8200 \mathrm{~m}^{3} / \mathrm{s}$ ) was highest for this scenario, i.e. $9.8 \mathrm{~km}^{2}$ (Table 8).

\subsubsection{Sediment and heavy metal deposition}

The deposition amounts and patterns of sediment and heavy metals within the floodplains were influenced by the changing discharge regime and the landscaping measures in the scenarios. The increased occurrence of higher discharges due to climate change (Fig. 7) leads to a more frequent inundation of the floodplains and an increase in year-averaged sediment deposition from 1.15 to $1.81 \mathrm{~mm}$ (58\%) over the floodplain area (Table 8 ). Local differences become clear when comparing Fig. 3a4 with Fig. 8b1. However, landscaping

Table 9

Summary statistics of aggregated ecotope surface area $\left(\mathrm{km}^{2}\right)$.

\begin{tabular}{|c|c|c|c|c|}
\hline Aggregated ecotope class ${ }^{\mathrm{a}}$ & Reference situation ${ }^{\mathrm{b}}$ & Green $^{c}$ & Orange $^{c}$ & Yellow $^{c}$ \\
\hline Main channel & $43.35(26.9)$ & $43.36(-0.1)$ & $43.35(-0.5)$ & $32.72(-7.2)$ \\
\hline Side channel & $6.25(3.9)$ & $10.74(2.8)$ & $11.19(2.9)$ & $24.57(11)$ \\
\hline Lake & $13.31(8.3)$ & $13.31(0.0)$ & $13.31(-0.1)$ & $12.8(-0.5)$ \\
\hline Sandy & $1.72(1.1)$ & $2.57(0.5)$ & $1.95(0.1)$ & $1.95(0.1)$ \\
\hline Agriculture & $7.34(4.6)$ & $3.94(-2.1)$ & $6.29(-0.7)$ & $1.32(-3.8)$ \\
\hline Production meadow & $47.35(29.4)$ & $23.65(-14.8)$ & $61.64(8.2)$ & $12.34(-21.9)$ \\
\hline Natural grassland & $15.56(9.7)$ & $29.27(8.4)$ & $14.11(-1.1)$ & $38.17(13.4)$ \\
\hline Herbaceous vegetation & $8.75(5.4)$ & $14.79(3.7)$ & $1.12(-4.7)$ & $22.42(8.1)$ \\
\hline Shrubs & $3.73(2.3)$ & $4.11(0.2)$ & $0.81(-1.8)$ & $5.03(0.7)$ \\
\hline Forest & $6.04(3.8)$ & $10.42(2.7)$ & $2.33(-2.3)$ & $6.15(0.0)$ \\
\hline Unvegetated & $2.31(1.4)$ & $1.09(-0.8)$ & $5.95(2.2)$ & $0.26(-1.3)$ \\
\hline Built-up & $5.34(3.3)$ & $4.44(-0.6)$ & $1.90(-2.2)$ & $7.88(1.4)$ \\
\hline Sum & $161.05(100)$ & $161.68(0.6)$ & $163.96(2.9)$ & $165.63(4.6)$ \\
\hline
\end{tabular}

a Ecotopes constituting the aggregated classes can be found in the ETM (Table 5).

b In brackets the percentage of the total area.

c In brackets the change in percent points relative to the reference situation. 
a) Ecotope distributions 2050

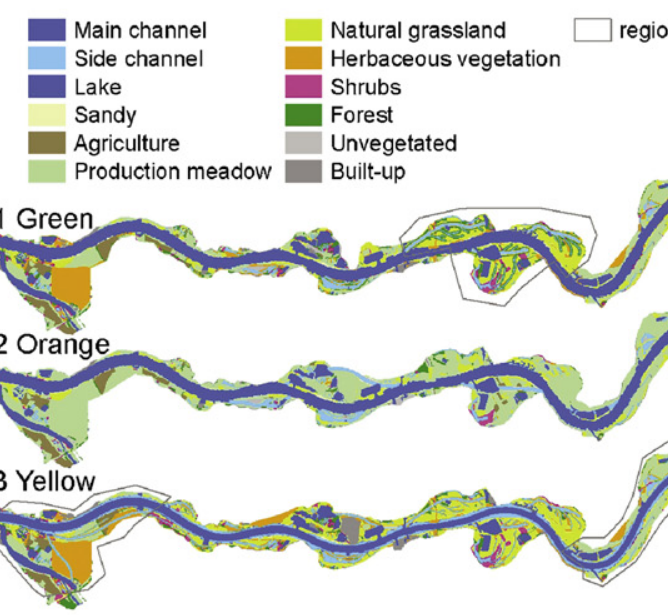

b) Deposition pattern of suspended sediment for KNMI-W discharge regime 2050

b1 Reference 2050
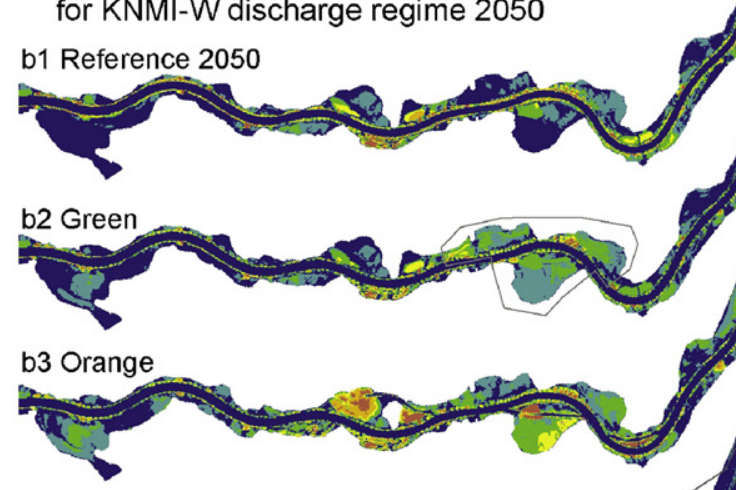

b4 Yellow
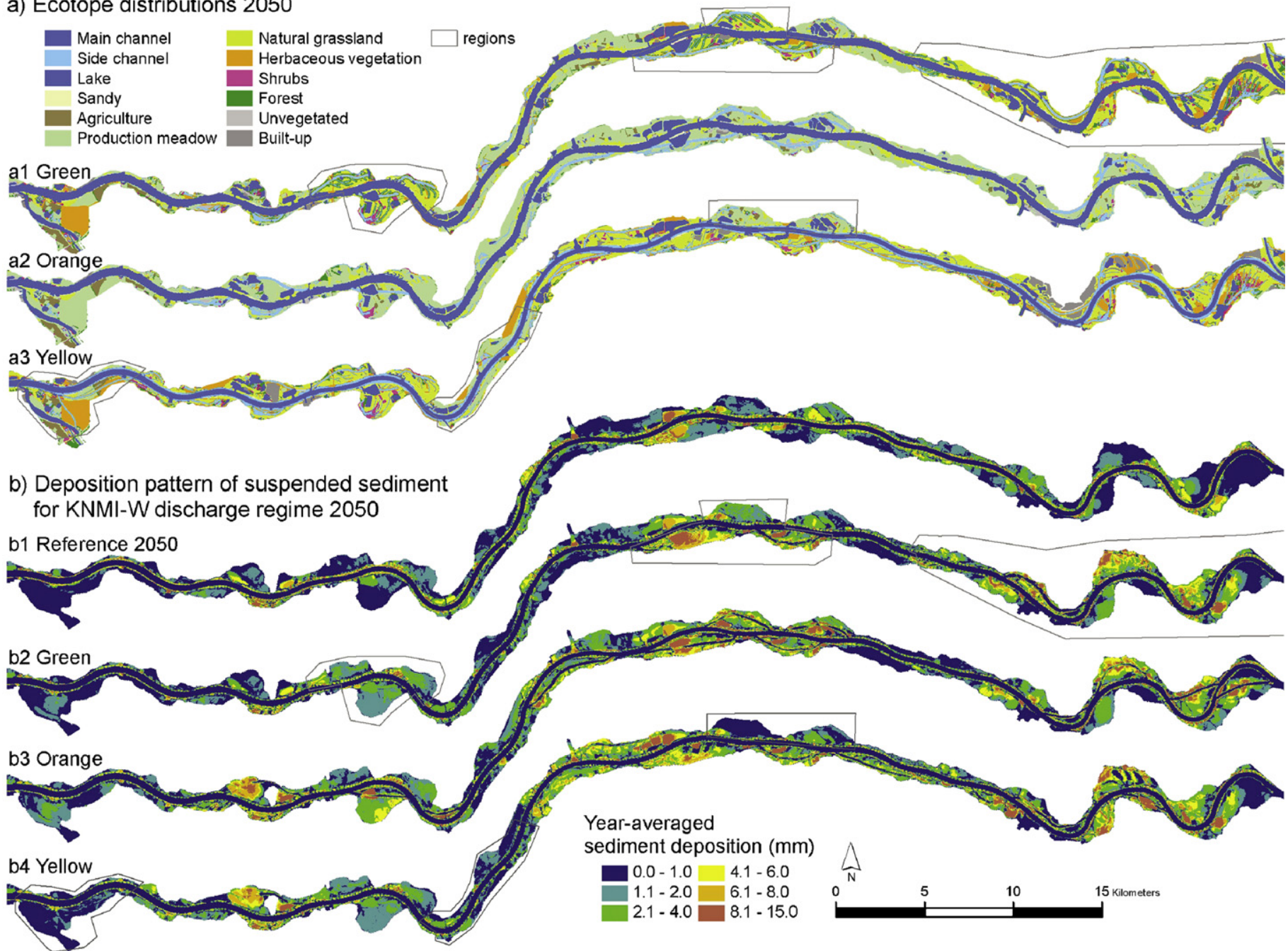

Fig. 8. (a) Ecotope distribution for the scenarios and (b) pattern of suspended sediment deposition in the Waal for the KNMI-W discharge regime. 


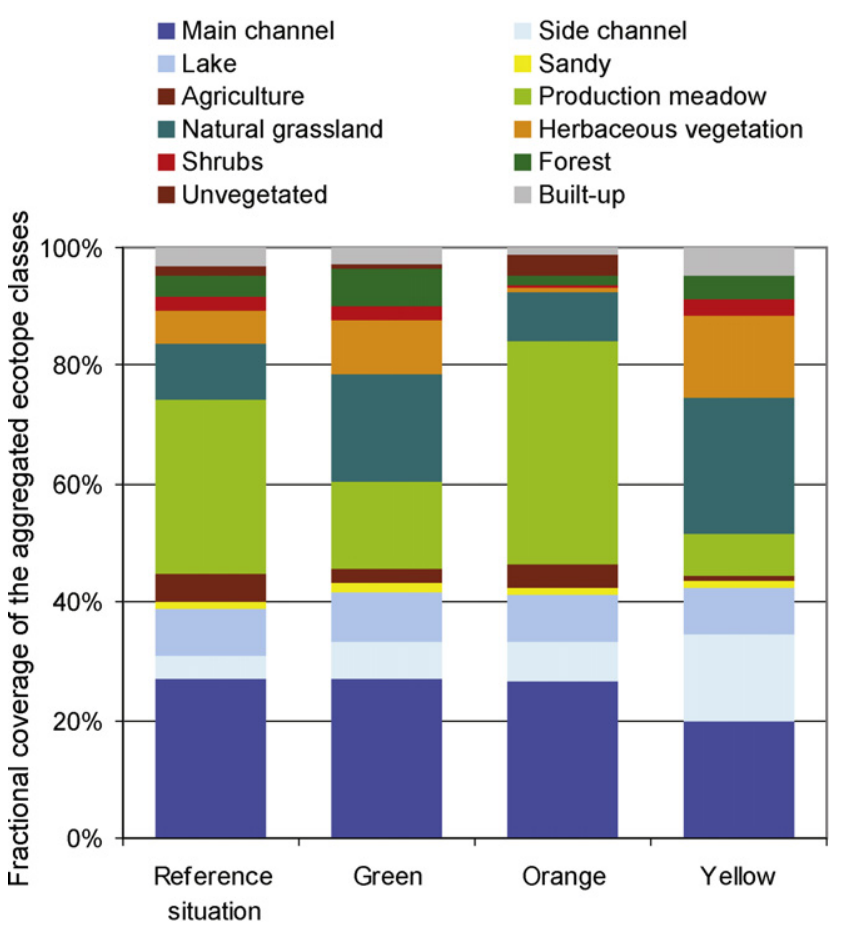

Fig. 9. Fractional coverage of the aggregated ecotope classes for the reference situation and for the scenarios.

measures more than double the floodplain sedimentation, which increases by $112-148 \%$ with respect to REF2001.

Spatial differentiation between the scenarios is large (Fig. 8b). In the orange scenario a relatively large amount of sediment is deposited in the upstream part of the study area at locations where the side channels connect upstream to the main channel. Bordering these side channels, new levees form with a deposition rate of $10 \mathrm{~mm} / \mathrm{y}$. In the yellow and green scenario, side channels connect only downstream to the main channel, which leads to lower sedimentation rates. Before digging the side channels, the deposition rate at these locations was less than $0.5 \mathrm{~mm} / \mathrm{y}$. Changes in deposition pattern of Cd largely follow the pattern in sediment deposition. The reference situation has the lowest $\mathrm{Cd}$ deposition rate $(655 \mathrm{~kg} / \mathrm{y})$, the orange scenario, the highest $(1372 \mathrm{~kg} / \mathrm{y}$; Table 8$)$. Little difference $(<10 \%)$ was present for the resulting Cd concentrations.

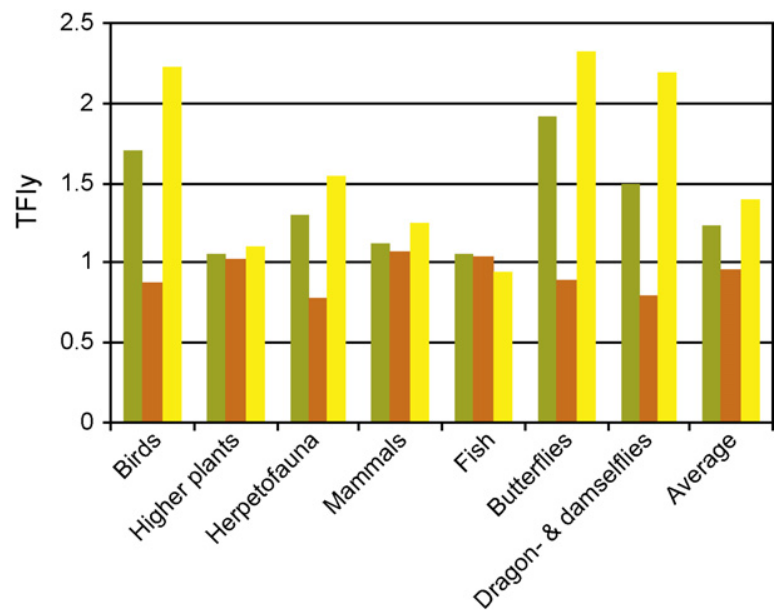

Fig. 10. Taxonomic group Floodplain Importance (TFI) scores for various taxonomic groups. Values are relative to the scores in the reference situation, hence all TFI scores for the reference situation would be one. Colors refer to scenarios.

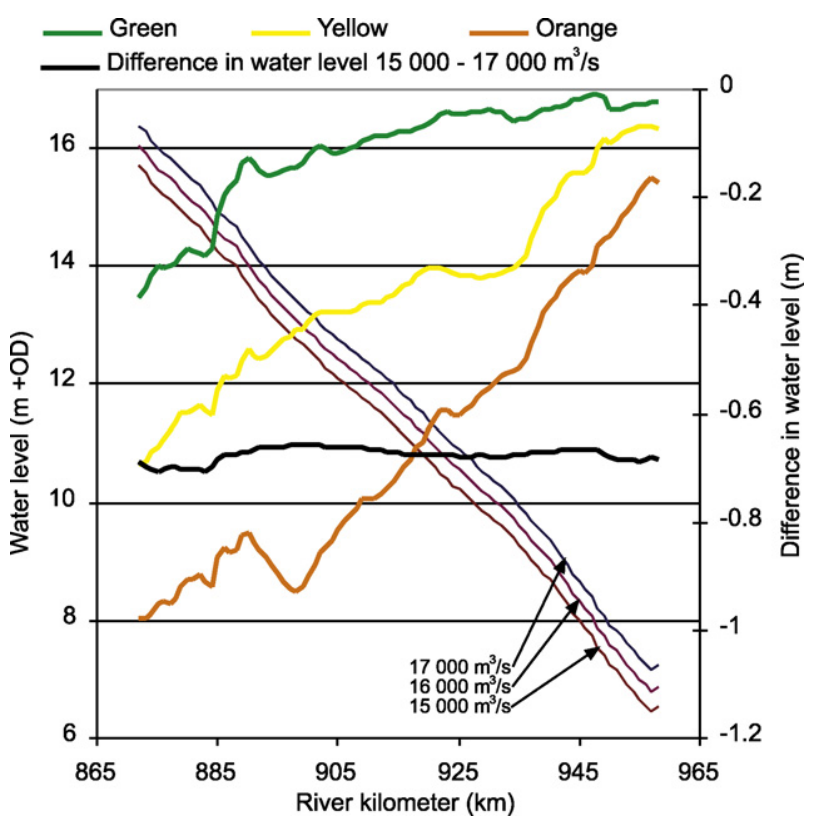

Fig. 11. Water surface levels relative to ordnance datum (OD, the daily average peak sea water level) for the reference situation at design discharges of 15,000,16,000 and $17,000 \mathrm{~m}^{3} / \mathrm{s}$ (left $y$-axis), and difference in water levels due to the landscaping measures of the green, orange and yellow scenario (right $y$-axis). River kilometer denotes the distance along the river axis from the start of the River Rhine. The difference in water level is the required effect of the landscaping measures without dike raising.

The filter function of the River Waal within the coastal zone is expressed as the total trapping efficiency of the river for suspended sediment, calculated for the discharges of $>3500 \mathrm{~m}^{3} / \mathrm{s}$ that cause floodplain inundation (Table 7). The reference situation with the current discharge regime shows a 26\% trapping efficiency and a total annual deposition of $0.2 \mathrm{Mton} / \mathrm{y}$. The reference situation in 2050 has a similar trapping efficiency of $27 \%$, with $0.3 \mathrm{Mton} / \mathrm{y}$ deposition. The orange scenario shows the highest trapping efficiency at $37 \%$ (Table 8).

\subsubsection{Ecotoxicological risks}

Predicted exposure concentrations (PECs) of cadmium for 10 terrestrial vertebrate species show practically no differences between the different scenarios (Table 10). Irrespective of scenario, for four species (i.e. common shrew, European mole, badger and little owl) the largest part of the habitat area remain characterized by PECs that are higher than the corresponding toxicity reference values (predicted no-effect concentrations (PNECs); Table 10). For the weasel, the PNEC is exceeded in a small fraction $(<1 \%)$ of the habitat area for three out of five scenarios. For the remaining five species, the entire habitat area is characterized by exposure concentrations lower than the corresponding PNECs.

\section{Discussion}

\subsection{SD method}

In this paper, we present a new method for developing and evaluating scenarios for river management strategies by integrating sociology with ecology and geomorphology. The structuring of scenarios around possible transitions in SD value systems enforces a focus on the underlying value patterns that influence the choices for the specific management strategies (Inayatullah, 1998). Analysis of value systems and possible transitions effectively creates a distance from current policies and convictions, and hence provides an excel- 
Table 10

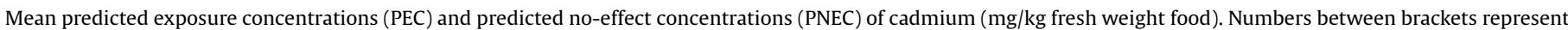
the fraction of habitat area where PEC $>$ PNEC.

\begin{tabular}{|c|c|c|c|c|c|c|}
\hline & REF2001 & REF2050 & Green & Orange & Yellow & $\mathrm{PNEC}^{\mathrm{C}}$ \\
\hline Bank vole & $0.11(0 \%)$ & $0.11(0 \%)$ & $0.11(0 \%)$ & $0.11(0 \%)$ & $0.12(0 \%)$ & 0.27 \\
\hline Common shrew & 1.16 (95.7\%) & $1.16(95.2 \%)$ & $1.19(98.8 \%)$ & 1.22 (98.9\%) & 1.22 (99.1\%) & 0.64 \\
\hline Common vole & $0.12(0 \%)$ & $0.12(0 \%)$ & $0.12(0 \%)$ & $0.13(0 \%)$ & $0.13(0 \%)$ & 0.36 \\
\hline European mole & $3.94(100 \%)$ & $3.95(100 \%)$ & $4.03(99.8 \%)$ & $4.09(100 \%)$ & $4.10(100 \%)$ & 0.42 \\
\hline Rabbit & $0.12(0 \%)$ & $0.12(0 \%)$ & $0.12(0 \%)$ & $0.13(0 \%)$ & $0.13(0 \%)$ & 0.36 \\
\hline Wood mouse & $0.13(0 \%)$ & $0.13(0 \%)$ & $0.14(0 \%)$ & $0.14(0 \%)$ & $0.14(0 \%)$ & 0.39 \\
\hline Badger & $2.98(99.7 \%)$ & $3.00(99.9 \%)$ & $3.06(99.5 \%)$ & $3.12(100 \%)$ & $3.11(100 \%)$ & 0.51 \\
\hline Kestrel & $0.23(0 \%)$ & $0.23(0 \%)$ & $0.24(0 \%)$ & $0.25(0 \%)$ & $0.26(0 \%)$ & 3.17 \\
\hline Little owl & $3.31(91.0 \%)$ & $3.28(90.2 \%)$ & 3.25 (87.6\%) & $3.45(95.6 \%)$ & $3.19(86.0 \%)$ & 2.48 \\
\hline Weasel & $0.37(0.1 \%)$ & $0.35(0.1 \%)$ & $0.36(0 \%)$ & $0.38(0.03 \%)$ & $0.38(0 \%)$ & 0.74 \\
\hline
\end{tabular}

a From Schipper et al. (2008a, b).

lent tool for long-term scenarios. Moreover, the wide range in value systems, from beige to turquoise, makes SD a generic framework for scenario development for any river basin where humans influence the fluvial environment. The present study illustrates the great potential for the application of SD in the design of floodplain management scenarios, as the shifts in value systems provide a guide for selecting and positioning specific landscaping measures. In addition, the value systems analysis promotes the internal coherence of the scenarios, as measures are chosen within a storyline rather than individually.

Compared to the IPCC scenarios (IPCC, 2000), the SD-based scenarios explicate the underlying values that combine drivers into storylines and consider transitions between value systems. Compared to Cultural Theory (Thompson et al., 1990) as a basis for scenarios, SD provides a wider set of value systems that may dominate river and floodplain management. This has the advantage of providing a broader interpretive framework, which at the same time limits the number of possible transitions by eliminating unrealistic transitions, such as blue to yellow.

Like any scenario methodology, the application of SD cannot entirely prevent arbitrary choices, such as the exact shape of side channels, or the exact location of specific landscaping measures, or transitions in the ETM. The selection and layout of the landscaping measures is a critical step in the process of scenario development. The application of a coherent value systems framework combined with the consensus obtained between different experts was assumed to limit the arbitrariness of the choices.

\subsection{Biogeomorphological changes}

We assessed the effects of the management strategies on the biogeomorphology of the Waal River floodplains by using detailed spatially distributed models. The allure of these models lies in the ability to maintain detail in the landscape while covering a large river reach. The modeling approach furthermore provides quantitative insights into the processes studied, when compared to for example a score table such as used by Middelkoop et al. (2004). Our modeling results revealed multifaceted effects of a changing discharge regime and landscaping measures on the biogeomorphology of the study area. Firstly, although the landscaping measures reduce the peak water levels (Fig. 11), the reduction is insufficient to refrain from additional measures. The wish of maintaining flood safety without dike raising is met only in the upstream part of the study area for the orange scenario. In the green and yellow scenarios, the increase in natural vegetation cover leads to additional roughness, thus decreasing the discharge capacity. Makaske and Maas (2007) found that nature development should be combined with intensive grazing to maintain discharge capacity in the floodplains. Secondly, due to the effect of climate change on the discharge regime, the overbank deposition of sediment will increase by $58 \%$. The removal of minor embankments and the addition of side channels in the scenarios lead to a $112-148 \%$ increase. Both measures improve the trapping efficiency of the lower Rhine. The year-averaged sedimentation of $0.2 \mathrm{Mton} / \mathrm{y}$ for the reference situation with the current discharge regime equals $12 \%$ of the total sediment flux of $1.7 \mathrm{Mton} / \mathrm{y}$ of the River Waal. This is in close agreement with Asselman and van Wijngaarden (2002), who found a value of $13 \%$ using a $1 \mathrm{D}$ model for all Rhine distributaries together. These deposition values can be regarded as minimum values, because SEDIFLUX does not compute the deposition of sand. Sedimentation reduces the cross-sectional area of the floodplain, which in the long term, limits the discharge capacity. Therefore, with a high sedimentation rate, landscaping measures like lowering of the floodplain will have to be repeated more often. Thirdly, the potential biodiversity values improve for the green and yellow scenario and decrease for the orange scenario, which is in line with expectations about effects of various types of landscaping measures (De Nooij et al., 2004). Finally, potential toxicological effects of cadmium contamination in the floodplain soil, as computed by SpaCE-S, were revealed for 4-5 out of 10 wildlife species. The cumulative fraction of affected habitat was similar among the different scenarios, due to the small differences in total Cd deposition and the application of one single value for Cd concentration within the soil profile. In reality, however the metal concentrations vary with soil profile depth (Middelkoop, 2000). This will lead to variation in exposure concentrations with excavation depth, which is particularly relevant when excavating floodplains.

Detailed aspects of the floodplain ecology, hydraulics and sediment deposition have been investigated in several previous studies (e.g. Middelkoop, 2002; Walling and Owens, 2003; Baptist et al., 2004; Geilen et al., 2004; Thonon, 2006; Schipper et al., 2008a). The additional value of the present study is that the consequences of management choices with respect to various geomorphological and ecological aspects are evaluated simultaneously as well as cohesively. For example, the orange scenario resulted in a large flood peak reduction and a considerable increase in high water refuge area for wildlife, but at the same time in high sedimentation rates and a decline of biodiversity potential. None of the scenarios showed the ideal combination of a high flood peak reduction, low sedimentation, low ecotoxicological risks, and high biodiversity.

\section{Conclusions}

We provided the first attempt to develop scenarios for floodplain management based on Spiral Dynamics (SD), and conclude that the value systems analysis provided a broad interpretive framework for development of scenarios that are internally coherent and plausible. We designed three floodplain management scenarios, with a time horizon of 2050, for the main distributary of the River Rhine in the Netherlands based on transitions in value systems. Using the SD value systems framework, three fundamentally different sets of landscaping measures were composed: 
- The green relativistic scenario incorporated measures in three regions where consensus was found. Measures comprised side channels with naturally vegetated banks, 32 floodplain lowering projects, three dike section relocations, minor embankment removal, and natural management of ecotopes.

- The orange multiplistic scenario was characterized by a productive-efficient layout applied to the entire study area. Measures comprised deep side channels with unvegetated banks, 51 floodplain lowering projects, minor embankment removal, and emphasized agricultural production.

- The yellow systemic scenario showed a diverse pattern of city expansion, nature development, agricultural production and innovative groyne lowering. It comprised 52 floodplain height change projects, minor embankment removal outside the production regions, and seven dike repositioning projects.

The river floodplain biogeomorphology is influenced by the combined effects of a climate-induced change in discharge regime and local landscaping measures. Climate-induced changes in river discharge regime may increase the year-average floodplain sedimentation by the order of $50 \%$ but it is overshadowed by the increase due to human landscaping measures of more than $100 \%$. Therefore, we conclude that the filter function of this lowland river is more sensitive to local measures than changes in discharge regime. The trapping efficiency is positively correlated to floodplain discharge capacity. The orange scenario provided the extreme case of high discharge and high deposition.

The average flood peak reduction (green 0.11, orange 0.65 and yellow $0.37 \mathrm{~m}$ ) did not compensated for the increase in water level from higher peak discharges rendering additional measures necessary. Natural vegetation should be compensated for by sufficiently large side channels to increase discharge capacity and prevent driving up the water levels. The ecotoxicological risks of cadmium contamination remains similar (4, 5, 4 out of 10 species at risk), but it points at the knowledge gap on three-dimensional distribution of soil pollution. The scenarios also point to the human influence on future potential biodiversity values ranging from -4 to $+39 \%$. We conclude that none of the scenarios shows the ideal combination of a high flood peak reduction, low sedimentation, low ecotoxicological risks, and high biodiversity potential.

\section{Acknowledgements}

This work was funded by NWO, the Netherlands Organization for Scientific Research, within the framework of the LOICZ program under contract number 01427004. Claudia Michels (Ministry of Transport, Public Works and Water Management) is gratefully acknowledged for the Baseline data and consulting. Alex van Heezik (HNT historical productions) is thanked for supportive feedback on the historic overview. Marjolein Haasnoot (Wl|Delft Hydraulics), Rutger van de Brugge (DRIFT), Daphne Willems, and Emiel Kater (both ISIS) were very helpful in drawing the sketch maps of the scenarios.

\section{References}

Allison, M.A., Kuehl, S.A., Martin, T.C., Hassan, A., 1998. Importance of floodplain sedimentation for river sediment budgets and terrigenous input to the oceans: insights from the Brahmaputra-Jamuna river. Geology 26, 175178.

Anonymous, 2007. Planologische kernbeslissing: Room for the River (key Decision on Spatial Planning: Room for the Rhine Branches). Space for the River, Project Office (in Dutch).

Asselman, N.E.M., van Wijngaarden, M., 2002. Development and application of a 1D floodplain sedimentation model for the River Rhine in The Netherlands. J. Hydrol. 268, 127-142.

Baptist, M.J., Penning, W.E., Duel, H., Smits, A.J.M., Geerling, G.W., Van der Lee, G.E.M., et al., 2004. Assessment of the effects of cyclic floodplain rejuvenation on flood levels and biodiversity along the Rhine River. River Res. Appl. 20, 285297.

Beck, E.D., Cowan, C.C., 1996. Spiral Dynamics; Mastering Values, Leadership and Change. Blackwell Publishers.

Braakhekke, W., 2007. Inspiratieatlas Waalweelde (Inspiration atlas Waalweelde) (No. 07.2.152). Innovatienetwerk, Utrecht (in Dutch).

Brierley, G.J., Fryirs, K.A., 2008. River Futures: An Integrative Approach to River Repair. Island Press, Washington, DC.

Buijse, A.D., Coops, H., Staras, M., Jans, L.H., Van Geest, G.J., Grifts, R.E., et al., 2002. Restoration strategies for river floodplains along large lowland rivers in Europe. Freshwater Biol. 47, 889-907.

Cowan, C.C., Todorovic, N., 2007. Spiral Dynamics Overview. Retrieved 28.7.2008 from www.spiraldynamics.org/aboutsd_theory.htm.

De Nooij, R.J.W., Lenders, H.J.R., Leuven, R.S.E.W., De Blust, G., Geilen, N., Goldschmidt, B., et al., 2004. BIO-SAFE: assessing the impacts of physical reconstruction on protected and endangered species. River Res. Appl. 20, 299313.

De Nooij, R.J.W., Lotterman, K.M., Van de Sande, P.H.J., Pelsma, T., Leuven, R.S.E.W., Lenders, H.J.R., 2006. Validity and sensitivity of impact assessments for target species in river systems. Environ. Impact Assess. 26, 677-695.

Deil, U., 2005. A review on habitats, plant traits and vegetation of ephemeral wetlands-a global perspective. Phytocoenologia 35, 533-706.

Geilen, N., Jochems, H., Krebs, L., Muller, S., Pedroli, B., Van der Sluis, T., et al., 2004. Integration of ecological aspects in flood protection strategies: defining an ecological minimum. River Res. Appl. 20, 269-283.

Graves, C., 2006. The Never Ending Quest: Clare W. Graves Explores Human Nature. ECLET Publishing, Santa Barbara, CA.

Grumbine, R.E., 1994. What is ecosystem management? Conserv. Biol. 8, 27-38.

Grumbine, R.E., 1997. Reflexions on"What is ecosystem management?". Conserv. Biol. 11, 41-47.

Hillman, M., Brierley, G., 2005. A critical review of catchment-scale stream rehabilitation programmes. Prog. Phys. Geogr. 29, 50-70.

Hin, J., Van de Laar, E., Menke, U., 2001. Definitiestudie bodemkwaliteitskaarten Rijntakken (Definition Study Soil Quality Map) (No. RIZA Report 2001.054). RIZA, Arnhem (in Dutch).

Inayatullah, S., 1998. Causal layered analysis: poststructuralism as method. Futures 30, 815-829.

IPCC, 2000. Special Report on Emission Scenarios. Cambridge University Press, Cambridge.

IPCC, 2007. Climate Change 2007-Impacts, Adaptation and Vulnerability. IPCC.

Jansen, B.J.M., Backx, J.J.G.M., 1998. Ecotopenkartering Rijntakken-Oost (Ecotope Mapping Rhine Branches-East 1997) (No. 98.054). RIZA, Lelystad (in Dutch).

Klijn, F., Samuels, P., Van Os, A., 2008. Towards flood risk management in the EU: state of affairs with examples from various European countries. Int. J. River Basin Manage. 6, 307-321.

Lenders, H.J.R., Leuven, R.S.E.W., Nienhuis, P.H., De Nooij, R.J.W., Rooij, V., 2001. BIOSAFE: a method for evaluation of biodiversity values on the basis of political and legal criteria. Landscape Urban Plan. 55, 121-137.

Makaske, B., Maas, G.J., 2007. Veiligheid en natuurbeheer in "Ruimte voor de Rivier" (Safety and Nature Management in "Room for the Rhine Branches") (No. AlterraReport 1624). Alterra, Wageningen (in Dutch).

Meade, R.H., 1982. Sources, sinks, and storage of river sediment in the Atlantic drainage of the United States. J. Geol. 90, 235-252.

Middelkoop, H., 2000. Heavy-metal pollution of the river Rhine and Meuse floodplains in the Netherlands. Netherlands J. Geosci. 79, 411-428.

Middelkoop, H., 2002. Reconstructing floodplain sedimentation rates from heavy metal profiles by inverse modelling. Hydrol. Process. 16, 47-64.

Middelkoop, H., Van der Perk, M., Thonon, I. 2003. Herverontreiniging van uiterwaarden langs de Rijntakken met sediment-gebonden zware metalen (Pollution of the Rhine distributary floodplains with sediment-attached heavy metals). ICG Rapport 03/3, Dep. of Physical Geography, Utrecht.

Middelkoop, H., Van Asselt, M.B.A., Van't Klooster, S.A., Van Deursen, W.P., Kwadijk, J.C.J., Buiteveld, H., 2004. Perspectives on flood management in the Rhine and Meuse rivers. River Res. Appl. 20, 327-342.

Middelkoop, H., Van der Perk, M., 1998. Modelling spatial patterns of overbank sedimentation on embanked floodplains. Geogr. Ann. A 80, 95-109.

RWS, 2007. Users Guide WAQUA: Technical Report SIMONA 92-10. Retrieved 13.02.2008, from http://www.waqua.nl/simona/release/doc/techdoc/ waquapublic/sim1999-01.pdf.

Schipper, A.M., Loos, M., Ragas, A.M.J., Lopes, J.P.C., Nolte, B., Wijnhoven, S., et al., 2008a. Modeling the influence of environmental heterogeneity on heavy metal exposure concentrations for terrestrial vertebrates in river floodplains. Environ. Toxicol. Chem. 27, 919-932.

Schipper, A.M., Loos, M., Ragas, A.M.J., Lopes, J.P.C., Nolte, B., Wijnhoven, S., et al., 2008b. Erratum to "Modeling the influence of environmental heterogeneity on heavy metal exposure concentrations for terrestrial vertebrates in river floodplains". Environ. Toxicol. Chem. 27, 2627-2628.

Shabalova, M.V., Van Deursen, W.P.A., Buishand, T.A., 2003. Assessing future discharge of the river Rhine using regional climate model integrations and a hydrological model. Climate Res. 23, 233-246.

Silva, W., Klijn, F., Dijkman, J., 2001. Room for the Rhine branches in The Netherlands (No. RIZA-report 2001.031, Delft Hydraulics Report R3294). RIZA, WL|Delft Hydraulics, Arnhem, Delft.

Straatsma, M.W., De Nooij, R.J.W., 2009. Evolution of River Management: Up to Integral and Beyond. Retrieved 20.12.2009, from http://faf-finalconference.science.ru.nl/paper\%20evolution\%20of\%20river.pdf. 
Thompson, M., Ellis, R., Wildavsky, A., 1990. Cultural Theory. Westview Press, Boulder, USA.

Thonon, I., 2006. Deposition of sediment and associated heavy metals on floodplains. Published PhD. Utrecht University, Utrecht.

Tockner, K., Stanford, J.A., 2002. Riverine flood plains: present state and future trends. Environ. Conserv. 29, 308-330.

Torres, K.C., Johnson, M.L., 2001. Bioaccumulation of metals in plants, arthropods, and mice at a seasonal wetland. Environ. Toxicol. Chem. 20, 2617-2626.

Van Ast, J., 2000. Interactief waterbeheer in grensoverschrijdende rivieren (Interactive Water Management in Transboundary Rivers). Eburon, Delft (in Dutch).

Van de Pas, B., 2005. Baseline Data Protocol, Baseline 3.31 (PR843.30). RIZA, Arnhem.

Van den Hurk, B.J.J.M., Klein Tank, A.M.G., Lenderink, G., van Ulden, A.P., van Oldenborgh, G.J., Katsman, C.A., et al., 2006. KNMI Climate Change Scenarios 2006 for the Netherlands. KNMI, de Bilt.

Van der Veer, G., 2006. Geochemical Soil Survey of the Netherlands. Published PhD. Utrecht University, Utrecht.
Van Heereveld, M.A., Leuven, R.S.E.W., Van Winden, A., Struiksma, N., 2007. Paper Presented at the Proceedings NCR-days 2007: A Sustainable River System?, Arnhem.

Van Notten, P.W.F., Rotmans, J., Van Asselt, M.B.A., Rothman, D.S., 2003. An updated scenario typology. Futures 35, 423-443.

Voros, J., 2006. Introducing a classification method for prospective methods. Foresight 8, 43-56.

Walling, D.E., Owens, P.N., 2003. The role of overbank floodplain sedimentation in catchment contaminant budgets. Hydrobiologia 494, 83-91.

Wijnhoven, S., Thonon, I., Van de Velde, G., Leuven, R.S.E.W., Zorn, M., Eijsackers, H.J.P., et al., 2006. The impact of bioturbation by small mammals on heavy metal redistribution in an embanked floodplain of the River Rhine. Water Air Soil Poll. $177,183-210$

Wolters, H.A., Platteeuw, M., Schoor, M.M., 2002. Guidelines for the Implementation of Ecological Measures along Rivers (No. 18-2002). NCR, Delft. 